\title{
Molecular docking prediction and in vitro studies elucidate anti-inflammatory effect of Garcinia extract against inducible nitric oxide synthase and cyclooxygenase-2 targets
}

\author{
Anuradha Kalita, Manas Das, Bhabajyoti Das and Momita Rani Baro
}

\begin{abstract}
Background: Garcinia is a tropical plant that has been traditionally used in medicinal folklore for its potential antioxidant, antibacterial, anti-hyperlipidemic, anti-diabetic, hepatoprotective, etc. In this study, methanolic extract of Garcinia herbal supplement (GME) and its important phytoconstituents (Garcinol and hydroxycitric acid) were evaluated for their inhibitory action against important inflammatory markers iNOS and COX-2 in lipopolysaccharideinduced RAW 264.7 cells. iNOS and COX-2 play a major role in the process of inflammation, and inhibition of these molecules will help to alleviate the inflammatory process. The cells were pre-treated with two doses of GME $(115 \mu \mathrm{g} /$ $\mathrm{ml}$ and $230 \mu \mathrm{g} / \mathrm{ml}) ;$ Ggarcinol $(6 \mu \mathrm{M}$ and $12 \mu \mathrm{M})$; hydroxycitric acid $(17.5 \mu \mathrm{g} / \mathrm{ml}$ and $35 \mu \mathrm{g} / \mathrm{ml})$ followed by stimulation with $1 \mu \mathrm{g} / \mathrm{ml}$ of LPS for $24 \mathrm{~h}$.

Results: The results of the study demonstrated that Garcinia and its active components Garcinol and HCA play an important role in suppressing LPS-induced relative mRNA expression of iNOS, COX-2, and subsequent reduction in the levels of total nitric oxide and prostaglandinE2. Molecular docking analysis of Ggarcinol and HCA with iNOS and COX-2 proteins showed potent interactions with negative binding energies.
\end{abstract}

Conclusions: This study suggests that Garcinia possess anti-inflammatory activity thus providing a possibility for drug designing as iNOS and COX-2 inhibitor.

Keywords: Garcinia, Lipopolysaccharide, Inducible nitric oxide synthase, Cyclooxygenase-2, Garcinol, Hydroxycitric acid

\footnotetext{
*Correspondence: manasdasne@gauhati.ac.in

Department of Zoology, Animal Physiology and Biochemistry Laboratory,

Gauhati University, Guwahati, Assam 781014, India
} 


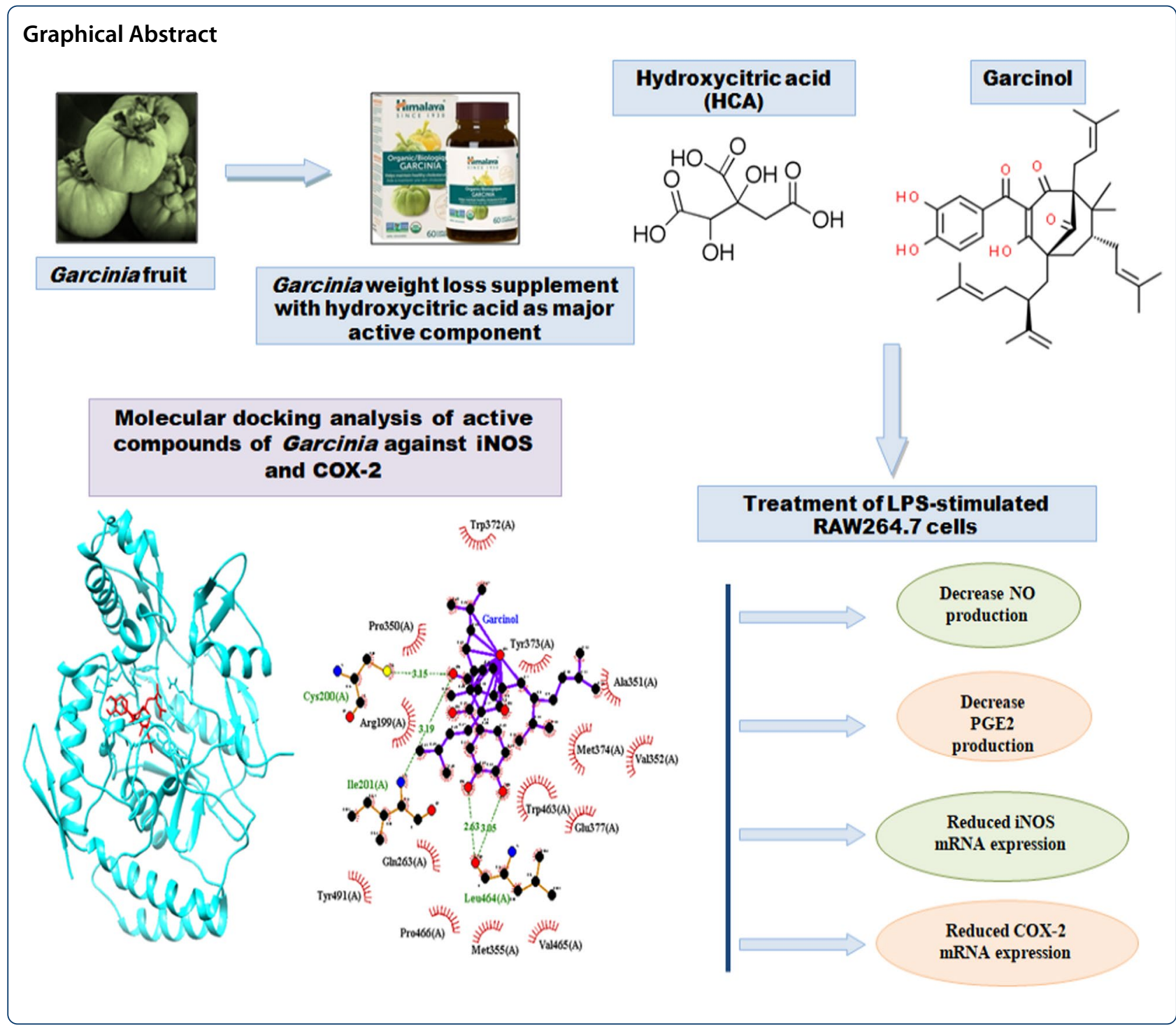

\section{Background}

The process of inflammation is mediated by several important mediators, out of which the inducible nitric oxide synthase (iNOS or NOS2) and cyclooxygenase-2 (COX-2) have been widely studied as markers of inflammation. iNOS is an enzyme that catalyzes the reaction leading to the production of nitric oxide (NO) from L-Arginine [1]. iNOS is mainly produced by macrophages in response to inflammatory stimuli. During the process of inflammation, macrophages increase the production of both $\mathrm{NO}$ and other free radicals to a great extent [2]. NO is a radical effector of the innate immune system [3]. NO can form other reactive nitrogen species (RNS) such as nitrogen dioxide $\left(\mathrm{NO}_{2}\right)$, dinitrogen trioxide $\left(\mathrm{N}_{2} \mathrm{O}_{3}\right)$, peroxynitrite anion $\left(\mathrm{ONOO}^{-}\right)$, nitrosothiols, and other nitrosating species. Generally, the immune cells are deficient in this enzyme. However, several of extracellular stimuli can trigger different signaling pathways causing the expression of iNOS. Lipopolysaccharide (LPS) is one of the most potent stimuli that activates the Toll-like receptor 4 (TLR4) and downstream signaling cascade [4]. Cyclooxygenases (COX) are enzymes that have three isoforms, namely COX-1, COX-2, and COX-3. Out of these three, COX-2 is mainly responsible for prostaglandinmediated inflammation [5]. COX converts arachidonic acid to prostaglandins [6]. Inhibition of these molecules will open up new avenues in the treatment of inflammation. Currently, synthetic anti-inflammatory drugs are being used to treat inflammation. However, these drugs possess many side effects, and thereby research has been going on to find out natural anti-inflammatory agents. From earlier times, herbal medicines have been 
regarded to be the best remedies for many disorders. The requirement of herbal products is therefore increasing exponentially for pharmacological applications for their important medicinal properties. Garcinia has been traditionally used in Indian medicine for its medicinal properties. The whole plant including the fruits, leaves, bark, and roots has been used for making remedies against several diseases [7]. Garcinia belongs to the family Clusiaceae and is widely distributed throughout the tropical regions. The genus has more than 200 species worldwide. However, some of the well-studied species of Garcinia include G.cambogia, G. mangostana, G. indica, G. kola, G. pedunculata, G. lanceifolia, G. xanthochymus, and G. cowa $[8,9]$. Garcinia is an important medicinal plant that possesses many important phytoconstituents. It has been traditionally used in tropical regions for its diverse medicinal properties. Evidence suggests that many important phytocompounds with anti-oxidant, anti-diabetic, anti-hyperlipidemic, anti-allergic, hepatoprotective, antibacterial, anti-inflammatory, neuroprotective as well as anti-cancer effects have been isolated from the fruit rind of Garcinia [10-18]. Garcinia plant is loaded with phenolic components including flavonoids, xanthones, benzophenones. The major therapeutic phytocompounds present in Garcinia include polyisoprenylated benzophenones such as garcinol, isogarcinol, camboginol, xanthochymol, and isoxanthochymol $[19,20]$. The major active components of Garcinia are known to be extracted from the fruit rinds. Also, the fruits are rich in organic acids such as citric acid, acetic acid, malic acid, ascorbic acid, hydroxycitric acid [20, 21]. Garcinia herbal extract with high HCA content is available in the form of oral supplements well-known for weight loss and is marketed by different brand names. Garcinol, a polyisoprenylated benzophenone derivative, is one of the phytoconstituents that has been isolated from the fruit rind of Garcinia [20, 22-25]. Studies suggest that Ggarcinol could be a positive anti-inflammatory agent $[25,26]$. In vitro study using IL-1 $\beta$-Induced chondrocyte inflammation has reported the protective effect of Garcinol against osteoarthritis by reducing the secretion of proinflammatory cytokines such as IL- 6 and TNF- $\alpha$; iNOS and COX-2 expression [27]. Also, apart from Garcinol, the Garcinia acid or hydroxycitric acid (HCA) is one of the active components that attribute to the weight loss properties of Garcinia extract [22, 28]. The dried fruit of the Garcinia consists of 30 to 50\% HCA. HCA has been generally used for its anti-inflammatory activities [29]. It has been known to reduce oxidative stress in some experimental models of inflammation [30-32]. The exact mechanism of the anti-inflammatory effects of Garcinia remains unclear. However, there is a possibility that phytocompounds exhibit their anti-inflammatory effects by inhibiting inducible nitric oxide synthase (iNOS) and cyclooxygenase-2 (COX-2) expression.

In our previous study using the LPS-challenged rat model, it was observed that Garcinia herbal extract significantly inhibited the iNOS and COX-2 expression and also led to a subsequent decrease in the enzyme activities and serum NO and PGE2 levels [33]. The LC/MS analysis of GME has shown the presence of many important phytocompounds. The major active constituents found to be present in GME were hydroxycitric acid (HCA) and Garcinol [33]. Therefore, in this study, we aim to investigate the inhibitory potential of the GME and the active constituents present, namely Garcinol and HCA against iNOS and COX-2 in LPS stimulated RAW 264.7 cells. In addition, we evaluate the plausible mechanism of extracts' inhibitory role through in silico analysis using molecular docking studies to find out the potential interactions of $\mathrm{HCA}$ and Garcinol with the target proteins iNOS and COX-2.

\section{Methods}

\subsection{Maintenance of cell line}

The murine macrophage cell line (RAW264.7) was purchased from National Centre for Cell Science (NCCS), Pune, India. The cell line was maintained in the cell culture laboratory of the Department of Zoology, Gauhati University. The cell line was grown in Dulbecco's modified eagle's medium or DMEM (HiMedia). The media was supplemented with $10 \%(\mathrm{v} / \mathrm{v})$ fetal bovine serum (FBS), $100 \mathrm{U} / \mathrm{ml}$ Penicillin, and $100 \mu \mathrm{g} / \mathrm{ml}$ Streptomycin. The cell line was maintained at $37{ }^{\circ} \mathrm{C}$ and $5 \% \mathrm{CO}_{2}$ in a $\mathrm{CO}_{2}$ incubator. The cells were tested for any kind of Mycoplasma contamination before the experiments following the PCR-based method $[34,35]$.

\subsection{Chemicals}

LPS (E. coli serotype O111: B4, Sigma-Aldrich, USA) stock solution of $1 \mathrm{mg} / \mathrm{ml}$ was prepared in $1 \mathrm{X}$ PBS and stored in aliquots at $-20{ }^{\circ} \mathrm{C}$ until the experiment. The methanolic extract of commercially available Garcinia herbal supplement (Himalaya, Lot No.: 11702264) was prepared for in vitro treatment. (-)-Hydroxycitric acid lactone (Sigma-Aldrich, USA, CAS No. 27750-13-6) stock solution of $5 \mathrm{mg} / \mathrm{ml}$ was prepared in miliQ water, and further dilution was done in DMEM. Similarly, Garcinol (Sigma-Aldrich, USA, CAS No.78824-30-3) stock solution was prepared by dissolving in $0.25 \% \mathrm{DMSO}$ in miliQ water to make 20-mM stock solution, and further dilution was done in DMEM [36].

\subsection{Determination of LPS dose}

The LPS dose for stimulation of RAW264.7 cells was determined using the nitric oxide assay. The production 
of nitric oxide in the culture medium of control and LPS treated RAW 264.7 cells was measured using the nitric oxide estimation kit (HiMedia) following the manufacturer's protocol. The RAW 264.7 cells were seeded in a 6-well culture plate at a density of $2 \times 10^{5}$ cells/well and allowed to settle for $16 \mathrm{~h}$. After $16 \mathrm{~h}$ of incubation, the medium was discarded and the cells were treated with fresh medium containing different doses of LPS $(0,0.5$, $1,1.5,2$, and $3 \mu \mathrm{g} / \mathrm{ml})$. 24-h post-treatment, $100 \mu \mathrm{l}$ of cell culture supernatant was used for TNO estimation. A triplicate set was taken for the measurement of each sample.

\subsection{Cell viability assay and $I C_{50}$ determination}

To ascertain the $\mathrm{IC}_{50}$ dose for GME, Garcinol, and HCA cell viability assay was performed using the MTT reagent (HiMedia). The effect of GME, Garcinol, and HCA on cell viability was investigated using the MTT assay. RAW264.7cells were seeded in 96-well plates at a density of $1 \times 10^{4}$ cells/well and allowed to settle for $12 \mathrm{~h}$ at $37^{\circ} \mathrm{C}$. The culture medium was then discarded, and fresh media containing different concentrations of GME (0, $100,200,300,400,500,600,700,800,900$, and $1000 \mu \mathrm{g} /$ $\mathrm{ml})$; Garcinol (0, 10, 20, 30, 40, 50, 60, 70, 80, 90, and $100 \mu \mathrm{M})$; and HCA $(0,10,20,30,40,50,60,70,80,90$, and $100 \mu \mathrm{g} / \mathrm{ml}$ ) was added and then incubated for $48 \mathrm{~h}$ at $37^{\circ} \mathrm{C}$. Post-incubation, $10 \mu \mathrm{l}$ of MTT was added to each well and further incubated for $3-4 \mathrm{~h}$ at $37{ }^{\circ} \mathrm{C}$. Next, the media containing MTT was discarded, and $100 \mu \mathrm{l} /$ well of solubilizing reagent (dimethyl sulfoxide) was added and then incubated overnight. The absorbance of the plate was read at $570 \mathrm{~nm}$ and $630 \mathrm{~nm}$ with a microplate reader. The $\mathrm{IC}_{50}$ value of GME, Garcinol, and HCA was evaluated from the MTT assay results.

\subsection{Cell treatment}

The cell experiments were divided into eight groups: control group, LPS treatment group, GME $(115 \mu \mathrm{g} / \mathrm{ml})+\mathrm{LPS}$ treatment group, $\operatorname{GME}(230 \mu \mathrm{g} / \mathrm{ml})+\mathrm{LPS}$ treatment group, Garcinol $(6 \mu \mathrm{M})+$ LPS treatment group, Gar$\operatorname{cinol}(12 \mu \mathrm{M})+\mathrm{LPS}$ treatment group, $\mathrm{HCA}(17.5 \mu \mathrm{g} /$ $\mathrm{ml})+$ LPS treatment group, $\mathrm{HCA}(35 \mu \mathrm{g} / \mathrm{ml})+$ LPS treatment group. RAW 264.7 cells were cultured in $100-\mathrm{mm}$ dishes at a density of $10^{6} \mathrm{cells} / \mathrm{cm}^{2}$ and allowed to settle for $16 \mathrm{~h}$. After $16 \mathrm{~h}$ of incubation, the medium was discarded and the cells were pre-treated with medium containing $115 \mu \mathrm{g} / \mathrm{ml}$ and $230 \mu \mathrm{g} / \mathrm{ml}$ of GME; $6 \mu \mathrm{M}$ and $12 \mu \mathrm{M}$ of Garcinol; $17.5 \mu \mathrm{g} / \mathrm{ml}$ and $35 \mu \mathrm{g} / \mathrm{ml}$ of HCA for $12 \mathrm{~h}$ except for the control and LPS treated groups and then the medium was discarded. The cells were then stimulated with $1 \mu \mathrm{g} / \mathrm{ml}$ LPS for $24 \mathrm{~h}$ except for the control group.

\subsection{Determination of total nitric oxide (TNO) level}

The production of TNO in the culture medium of treated cells was measured using the NO estimation kit (HiMedia) following the manufacturer's protocol. 24-h post-LPS treatment, $100 \mu \mathrm{l}$ of cell culture supernatant was used for total nitric oxide (TNO) estimation. A triplicate set was taken for the measurement of each sample. This assay is based on the reduction of nitrate $\left(\mathrm{NO}^{-}\right)$to nitrite $\left(\mathrm{NO}^{-}\right)$by a reducing agent at $37^{\circ} \mathrm{C}$. Converted nitrite and endogenous nitrite are collectively converted by Griess reagent to a blue-colored azo compound. This compound can be measured spectrophotometrically between $580-630 \mathrm{~nm}$, and absorbance is directly proportional to the TNO concentration in the sample which is calculated from the standard plot of NaNO3.

\subsection{Prostaglandin E2 assay}

The cells were washed with pre-cooled PBS and dissociated the cells by scraping. The cell suspension was collected and centrifuged for $5 \mathrm{~min}$ at $1000 \times \mathrm{g}$. The medium was discarded and cells were washed 3 times with pre-cooled PBS. For every $1 \times 10^{6}$ cells, $150-250 \mu \mathrm{l}$ of pre-cooled PBS was added to keep the cells suspended. The freeze-thaw process was repeated several times until the cells were fully lysed followed by centrifugation for $10 \mathrm{~min}$ at $1500 \times \mathrm{g}$ at $2-8^{\circ} \mathrm{C}$. The resultant supernatant was used to carry out the assay using the PGE2 ELISA kit (Elabscience ${ }^{\circledR}$, USA) following the manufacturer's instructions. The kit uses the SandwichELISA principle.

\subsection{RNA isolation and CDNA synthesis}

For total RNA isolation, the cells were washed with icecold PBS 24-h post-LPS treatment. RNA was extracted with spin column followed by NucleoSpin RNA Plus, Mini kit for RNA purification with DNA removal column (Macherey-Nagel) according to the manufacturer's instructions. RNA (0.5 $\mu$ g per sample) was reverse transcribed to cDNA using a first-strand cDNA synthesis kit (High Capacity, ThermoFisher Scientific) following the manufacturer's protocol. For real-time qPCR studies, the cDNA samples were diluted 50 times with sterile miliQ water.

\subsection{Designing of primers}

For real-time quantitative PCR amplification, the gene-specific primers for inos, cox-2, and gapdh were designed from species-specific cDNA sequences available in the NCBI database (accession numbers given in Table 1 with the help of primer-BLAST (NCBI), and the properties were checked using Oligo Calculator [37]. 
Table 1 Primer sequences used for real-time qPCR analysis

\begin{tabular}{llllc}
\hline Gene & Forward primer $\left(\mathbf{5}^{\prime} \boldsymbol{\rightarrow} \mathbf{3}^{\prime}\right)$ & Reverse primer $\left(\mathbf{5}^{\prime} \boldsymbol{\rightarrow} \mathbf{3}^{\prime}\right)$ & Accession number & $\begin{array}{l}\text { Product } \\
\text { size }(\mathbf{b p})\end{array}$ \\
\hline inos & CTATGGCCGCTTTGATGTGC & TTGGGATGCTCCATGGTCAC & U43428.1 & 111 \\
cox-2 & TCACGTGGAGTCCGCTTTAC & CCTTCGTGAGCAGAGTCCTG & NM_011198.4 & 112 \\
gapdh & ATGTGTCCGTCGTGGATCTG & GTGTAGCCCAAGATGCCCTT & GU214026.1 & 115 \\
\hline
\end{tabular}

The specificity of primers was checked by inspecting the PCR amplicons on 1.2\% agarose gel. The details of primer for real-time qPCR studies are shown in Table 1.

\subsection{Real-time qPCR analysis}

Real-time qPCR analysis was performed with the cDNA using different sets of primers used in the study (Table 1) with the help of Qiagen (Rotor-GeneQ). The relative abundance of the mRNA transcripts, in each sample, was normalized to the amount of an endogenous gene, gapdh. $10 \mu \mathrm{l}$ TB Green PCR Master mix (TAKARA), $2.8 \mu \mathrm{l}$ of each forward and reverse primers $(10 \mu \mathrm{M})$, and $2 \mu \mathrm{l}$ of cDNA template were used; and qPCR reactions were performed with thermal cycling conditions: denaturation at $95^{\circ} \mathrm{C}$ for $10 \mathrm{~min}$, followed by 45 cycles of denaturation at $95^{\circ} \mathrm{C}$ for $15 \mathrm{~s}$, primer annealing at respective annealing temperatures for the $30 \mathrm{~s}$ and extension at $72{ }^{\circ} \mathrm{C}$ for $30 \mathrm{~s}$. Relative mRNA concentrations of the transcripts in the experimental groups were determined as fold change to the control by following the $2^{-\Delta \Delta C T}$ method $[38,39]$. The melt curve analysis was performed to check for any nonspecific amplification during qPCR analysis.

\subsection{Molinspiration}

Molinspiration tool is used to execute QSAR studies to identify possible activators of biological objects. This online tool helps to calculate significant molecular properties of ligands including logP, polar surface area, number of hydrogen bond donors, number of hydrogen bond acceptors, and prediction of the bioactivity score for the majority of chief drug targets [40]. Lipinski's rule of five was applied to Garcinol and HCA [41]. The mol files and smile formula of Garcinol and HCA were obtained from the CHEMSPIDER database [42].

\subsection{Molecular docking}

\subsubsection{Protein preparation}

The PDB structures of iNOS (PDB ID: 2NSI) and COX-2 (PDB ID: 6COX) were retrieved from RCSB Protein Data Bank (http://www.rcsb.org/pdb/). The protein molecules were optimized (Fig. 1). The water molecules, hetero atoms were removed from the crystal structures with the help of Chimera 1.15. Polar hydrogens and Kollman charges were added, and the autodock structures (pdbqt file) were constructed with the help of the Autodock tool (ADT) [43].

\subsubsection{Ligand preparation}

The structures of Garcinol (PubChem CID-5281560) and HCA (PubChemCID-185620) were retrieved as an SDF file from PubChem database (https://pubchem.ncbi. nlm.nih.gov) [44]. The file was converted to PDB format with the help of Open Babel software (http://openbabel. org) [45]. To carry out molecular docking, the ligand was optimized, energy minimization was performed, and the pdbqt file was constructed with the help of the Autodock tool (ADT) [43].

\subsubsection{Grid box set-up and docking}

Molecular docking was carried out with garcinol and HCA against iNOS and COX-2 with the help of the AutoDock 4.2.6 program [43]. The binding site residues of the proteins were predicted using CASTp 3.0 [46]. A grid box enclosing the binding site residues of the target proteins was created to achieve the best conformational space. The grid box parameters are shown in Tables 2, 3 . Lamarckian Genetic Algorithm was used to carry out the docking. The resultant docked poses were chosen based on their binding energies and intermolecular $\mathrm{H}$-bonds. The $\mathrm{H}$-bond and hydrophobic interactions between protein-ligand complexes were analyzed using the LigPlot + tool [47].

\subsection{Statistical analysis}

Experiments were conducted in triplicates, and all the parameters were presented as mean \pm SEM. The statistical significance was calculated by one-way ANOVA, followed by Tukey's post hoc test using SPSS software. The results were considered statistically significant when $p<0.05$.

\section{Results}

\subsection{Effects of GME, Garcinol, and HCA on RAW264.7 cell viability}

The present study reported significant $(p<0.05)$ inhibition of RAW264.7 cell viability post-treatment with GME, Garcinol, and HCA for $48 \mathrm{~h}$. The $\mathrm{IC}_{50}$ of GME, Garcinol and HCA for RAW264.7 cells as calculated 


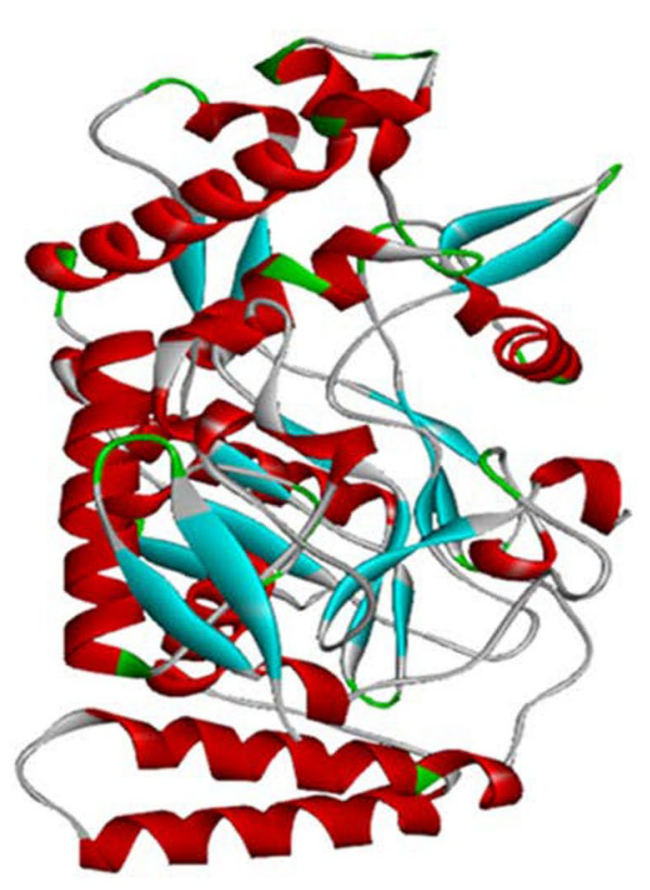

(a)

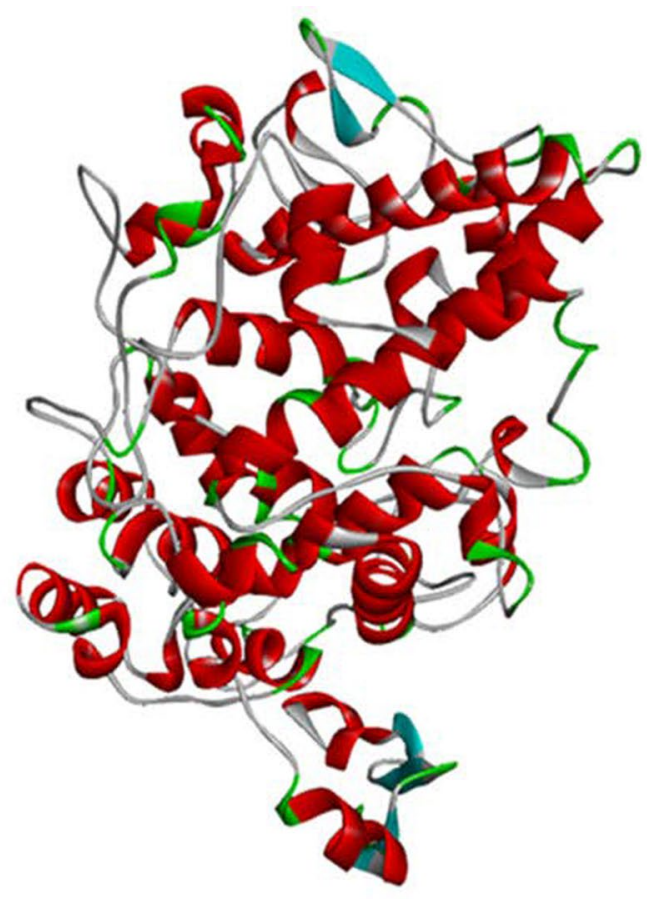

(b)

Fig. 1 Optimized structures of (a) iNOS and (b) COX-2 (BIOVIA Discovery StudioVisualizer)

Table 2 Properties of ligands analyzed using Molinspiration

\begin{tabular}{lllllllr}
\hline Ligands & CHEMSPIDER ID & LogP & $\begin{array}{l}\text { H-bond } \\
\text { acceptor }\end{array}$ & H-bond donor & Mol wt & No. of violation & TPSA \\
\hline Hydroxycitric acid & 110,439 & -2.90 & 8 & 5 & 208.12 & 0 & 152.35 \\
Garcinol & $10,199,485$ & 8.26 & 6 & 3 & 602.81 & 2 & 111.90 \\
\hline
\end{tabular}

from the regression equation was found to be $460 \mu \mathrm{g} /$ $\mathrm{ml}, 24 \mu \mathrm{M}$, and $70 \mu \mathrm{g} / \mathrm{ml}$, respectively. Based on the $\mathrm{IC}_{50}$, two different doses for GME $(230 \mu \mathrm{g} / \mathrm{ml}$ and $115 \mu \mathrm{g} / \mathrm{ml})$; Garcinol $(6 \mu \mathrm{M}$ and $12 \mu \mathrm{M})$; and HCA $(17.5 \mu \mathrm{g} / \mathrm{ml}$ and $35 \mu \mathrm{g} / \mathrm{ml})$ were selected for treatment of the cells (Figs. 2, 3, 4).

\subsection{Determination of LPS dose by NO assay}

The cells on treatment with different concentrations of LPS after $24 \mathrm{~h}$ showed a significant increase in the production of total nitric oxide. However, the maximum amount of total nitric oxide produced $24 \mathrm{~h}$ after LPS treatment was found at the concentration of $1 \mu \mathrm{g} /$ ml LPS by 6.99 fold $(p<0.001)$ as compared to control. Therefore, the LPS dose selected for the present study was $1 \mu \mathrm{g} / \mathrm{ml}$ (Fig. 5).

\subsection{Effects of GME, Garcinol, and HCA on morphology of LPS-stimulated RAW264.7 cells}

The cells were observed under the optical microscope (400X) 24-h post-treatment. The cells without LPS treatment showed a rounded form whereas the LPSstimulated cells showed an asymmetrical form as well as spindle shape with pseudopodia formation. The pretreatment of LPS-stimulated cells with GME, Garcinol, and HCA showed reduced level of pseudopodia formation. (Fig. 6).

\subsection{Effects of GME, Garcinol, and HCA on TNO production}

The results of the nitric oxide assay revealed that there was a significant increase in the TNO level by 4.30 -fold $(p<0.001)$ after $24 \mathrm{~h}$ of LPS exposure as compared to control. On the other hand, its levels was found to significantly decreased by -2.43 -fold $(p<0.05)$ in $230 \mu \mathrm{g} /$ ml GME; -1.92-fold $(p<0.05)$ and -3.19-fold $(p<0.01)$, 
Table 3 Grid box parameters for docking and binding site residues

\begin{tabular}{|c|c|c|c|c|}
\hline Protein & PDB ID & Binding site residues & Center grid box (points) & Grid size (points) \\
\hline iNOS & $2 \mathrm{NSI}$ & $\begin{array}{l}\text { MET120,THR121,LEU125,TRP194,ALA197,PRO198,ARG199, } \\
\text { CYS200,ILE201,GLY202,ILE204,GLN205,LEU209,SER242,ILE2 } \\
\text { 44,ARG258,TRP260,ASN261,ALA262,GLN263,ARG266,ALA2 } \\
\text { 82,ASN283,GLU285,PHE286,VAL305,TRP346,TYR347,,PRO3 } \\
\text { 50,ALA351,VAL352,ASN354,MET355,PHE369,ASN370,GLY3 } \\
\text { 71,TRP372,TYR373,MET374,THR376,GLU377,ARG381,ASP3- } \\
\text { 82,ASP385,GLN387,ARG388,MET434,ALA439,SER442,ILE46 } \\
\text { 2,TRP463,LEU464,VAL465,PRO466,PRO467,PHE488,,TY489, } \\
\text { TYR490,TYR491,GLN492,GLU494,ALA495,TRP496,LYS497 }\end{array}$ & $12.327 \times 61.831 \times 15.179$ & $108 \times 92 \times 96$ \\
\hline $\operatorname{cox}-2$ & $6 C O X$ & $\begin{array}{l}\text { ASN34,CYS36,CYS37,ASN39,PRO40,CYS41,GLN42,ASN43 } \\
\text {,ARG44,GLY45,GLU46,CYS47,MET48,ASP58,CYS59,,THR60 } \\
\text {,ARG61,THR62,GLY63,PHE64,GLU73,LEU75,THR76,LYS79, } \\
\text { LEU80,LEU82,LYS83,PRO84,THR85,PRO86,ASN87,VAL89,HI } \\
\text { S90,LEU93,MET113,LYS114,TYR115,VAL116,THR118,SER11 } \\
\text { 9,ARG120,SER121,TYR122,LEU123,,LE124,ASP125,SER126, } \\
\text { PRO127,PRO128,THR129,TYR130,GLY135,TYR136,LYS137, } \\
\text { THR149,ARG150,ALA151,LEU152,PRO153,PRO154,VAL155 } \\
\text {,ALA156,CYS159,GLN192,PHE205,PHE209,GLY227,VAL228, } \\
\text { VAL344,LE345,,TYR348,VAL349,LEU352,SER353,,TYR355,PH } \\
\text { E357,LEU359,LEU366,GLN369,GLN370,PHE371,GLN372,GL } \\
\text { N374,ASN375,ARG376,ILE377,ALA378,PHE381,LEU384,TYR } \\
\text { 385,TRP387,GLN461,GLU465,LYS468,ARG469,PHE470,SER4 } \\
\text { 71,LEU472,LYS473,PRO474,ARG513,ALA516,LE517,PHE518 } \\
\text {,GLU520,MET522,VAL523,GLU524,GLY526,ALA527,PRO528, } \\
\text { PHE529,SER530,LEU531,LYS532,GLY533,LEU534 }\end{array}$ & $29.245 \times 14.866 \times 35.875$ & $102 \times 118 \times 124$ \\
\hline
\end{tabular}

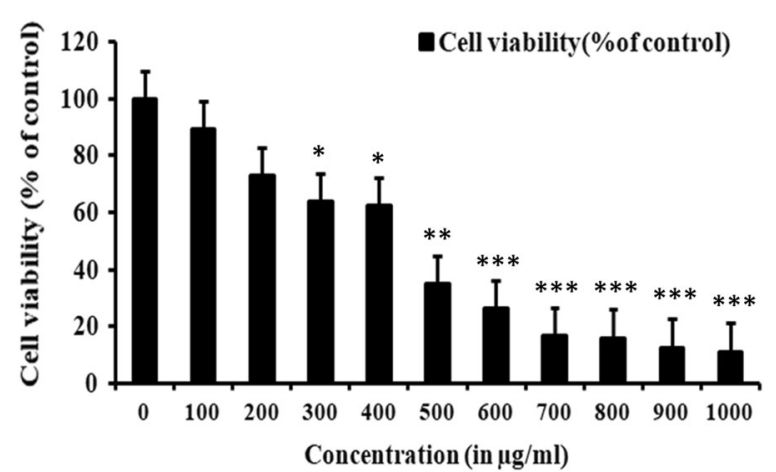

Fig. 2 Effect of GME on cell proliferation and viability of RAW 264.7 cells. Cells were treated with increasing concentrations of extracts for $24 \mathrm{~h}$; cell viability was determined with MTT cell proliferation reagent. Results were expressed as cell viability (\% of control). All data are expressed as mean \pm SEM $(n=3) .{ }^{*} p<0.05,{ }^{* *} p<0.01$ and ${ }^{* * *} p<0.001$ vs. $0 \mu \mathrm{g} / \mathrm{ml}$. The $\mathrm{IC}_{50}$ was calculated to be $460 \mu \mathrm{g} / \mathrm{ml}$

respectively, in the $6 \mu \mathrm{M}$ and $12 \mu \mathrm{M}$ Garcinol; -2.50fold $(p<0.05)$ and -2.71 -fold $(p<0.05)$, respectively, in $17.5 \mu \mathrm{g} / \mathrm{ml}$ and $35 \mu \mathrm{g} / \mathrm{ml} \mathrm{HCA}$ pre-treated cells as compared to the LPS-treated cells (Fig. 7a).

\subsection{Effects of GME, Garcinol, and HCA on PGE2 levels}

The results of the PGE2 assay revealed that there was a significant increase in the PGE2 level by 13.33-fold $(p<0.001) 24$-h post-LPS exposure as compared to control. On the other hand, its levels significantly decreased

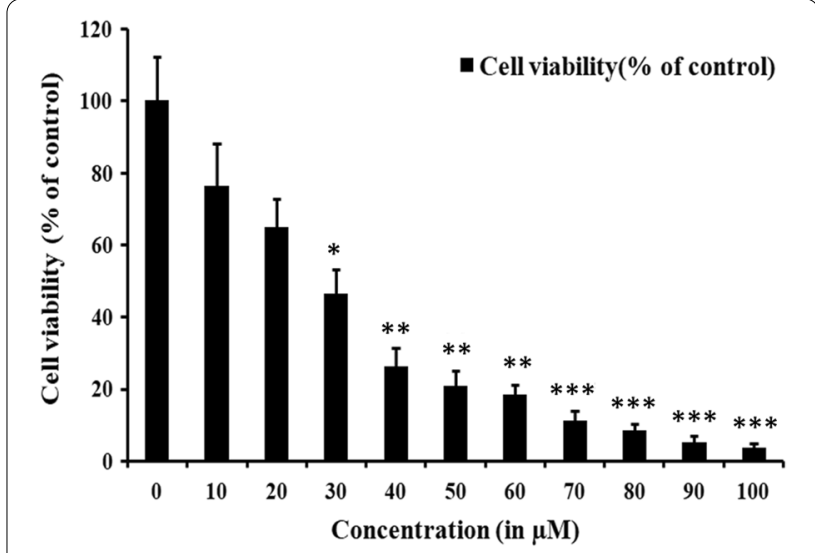

Fig. 3 Effect of Garcinol on cell proliferation and viability of RAW 264.7 cells. Cells were treated with increasing concentrations of Garcinol for 24 h; cell viability was determined with MTT cell proliferation reagent. Results were expressed as cell viability (\% of control). All data are expressed as mean $\pm \operatorname{SEM}(n=3) .{ }^{*} p<0.05$, ${ }^{* *} p<0.01$ and ${ }^{* *} p<0.001$ vs. $0 \mu \mathrm{M}$. The $I_{50}$ was calculated to be $24 \mu \mathrm{M}$

by -3.17 -fold $(p<0.01)$ and -5.28 -fold $(p<0.01)$, respectively, in the $115 \mu \mathrm{g} / \mathrm{ml}$ and $230 \mu \mathrm{g} / \mathrm{ml}$ GME; -5.97-fold $(p<0.01)$ and -7.31 -fold $(p<0.01)$, respectively, in $6-\mu \mathrm{M}$ and 12- $\mu \mathrm{M}$ Garcinol; -8.52-fold $(p<0.01)$ and -9-fold $(p<0.01)$, respectively, in $17.5 \mu \mathrm{g} / \mathrm{ml}$ and $35 \mu \mathrm{g} / \mathrm{ml} \mathrm{HCA}$ pre-treated cells as compared to the LPS treated cells (Fig. 7b). 


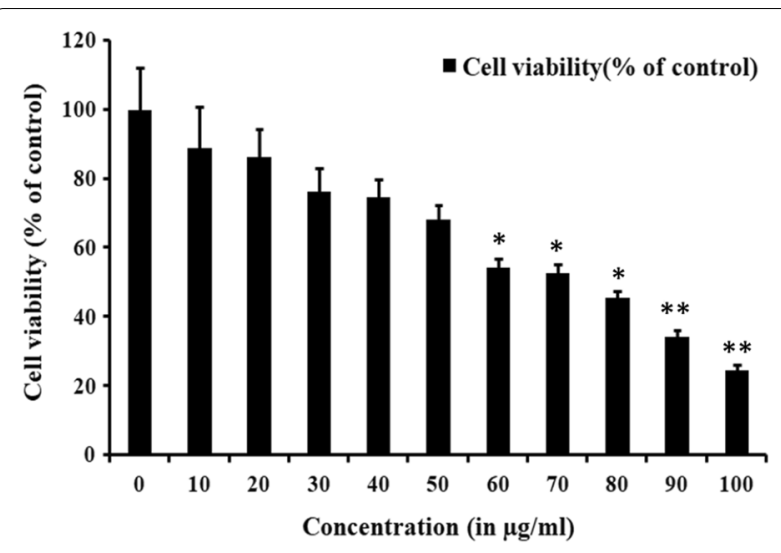

Fig. 4 Effect of HCA on cell proliferation and viability of RAW 264.7 cells. Cells were treated with increasing concentrations of HCA for $24 \mathrm{~h}$; cell viability was determined with MTT cell proliferation reagent. Results were expressed as cell viability (\% of control). All data are expressed as mean $\pm \operatorname{SEM}(n=3) .{ }^{*} p<0.05,{ }^{* *} p<0.01$ and ${ }^{* *} p<0.001$ vs. $0 \mu \mathrm{M}$. The $\mathrm{IC}_{50}$ was calculated to be $70 \mu \mathrm{g} / \mathrm{ml}$

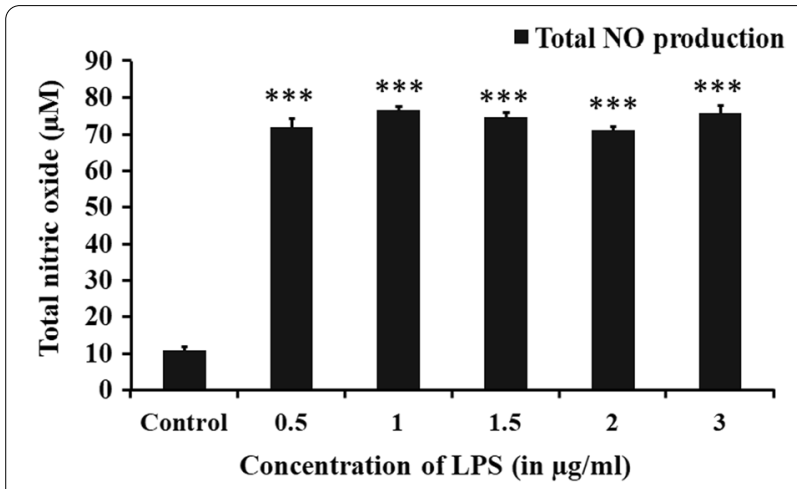

Fig. 5 LPS-induced total nitric oxide (TNO) production in RAW 264.7 cells. Cells were stimulated with the increasing $(0.5,1,1.5,2$, and $3 \mu \mathrm{g} / \mathrm{ml}$ ) concentrations of LPS for $24 \mathrm{~h}$ to determine the LPS dose for the study. The treated and untreated cell culture media were used to measure the amount of TNO to evaluate NO production. The level of TNO production in LPS stimulated cells were expressed as fold changes relative to the control group. All data are expressed as mean \pm SEM $(n=3)$. The values are statistically significant at ${ }^{*} p<0.05$; ${ }^{* *} p<0.01 ;{ }^{* *} p<0.001$ as compared to the control group (one-way ANOVA)

\subsection{Effects of GME, Garcinol, and HCA on mRNA expression of iNOS and COX-2}

The real-time qPCR studies revealed a significant increase in the transcript levels of inos, and cox-2 after $24 \mathrm{~h}$ of LPS treatment. Their transcript levels increased by 46.68 -fold $(p<0.001)$, and 12.98 -fold $(p<0.01)$ postLPS stimulation, respectively, as compared to control. The mRNA expressions of inos were however observed to be decreased significantly in the GME $(230 \mu \mathrm{g} /$ ml) pre-treated cells by -6.30 -fold $(p<0.01)$ and cox-2 mRNA expression was found to be decreased significantly in both the concentrations of GME $(115 \mu \mathrm{g} / \mathrm{ml}$ and $230 \mu \mathrm{g} / \mathrm{ml})$ by -1.90 -fold $(p<0.05)$, and -2.69 -fold $(p<0.05)$, respectively, as compared to the LPS treated cells. The inos and cox-2 transcripts levels were found to be decreased in Garcinol pre-treated cells, respectively, by -1.54 -fold $(p<0.05)$, and -3.47 -fold $(p<0.05)$ for $6 \mu \mathrm{M} ;-2.89$-fold $(p<0.01)$ and -3.02-fold $(p<0.05)$ for $12 \mu \mathrm{M}$ concentrations of Garcinol as compared to the LPS treated cells. Similarly, inos transcript level was found to be decreased by -3.76 -fold $(p<0.05)$ in $35 \mu \mathrm{g} /$ $\mathrm{ml}$ of HCA pre-treated cells. Also, the cox- 2 transcripts levels were found to be decreased, respectively, by -5.69 fold $(p<0.05)$ and -6.06 -fold $(p<0.05)$ in $17.5 \mu \mathrm{g} / \mathrm{ml}$ and $35 \mu \mathrm{g} / \mathrm{ml}$ of HCA pre-treated cells as compared to the LPS treated cells (Fig. 8a and b).

\subsection{Molinspiration analysis of Garcinol and HCA molecular properties}

The molecular properties of ligands Garcinol and HCA such as $\log \mathrm{P}$, number of hydrogen bond donors, number of hydrogen bond acceptors, the molecular weight was calculated using the Molinspiration tool (Table 2). HCA showed zero violations against Lipinski's rule of five. However, Garcinol with a molecular weight greater than 500 , i.e., $602.81 \mathrm{~g} / \mathrm{mol}$ and $\log \mathrm{P}$ value of 8.26 shows two violations against the rule of five.

\subsection{Molecular docking analysis}

Molecular docking studies were performed to elucidate the interaction between the targets (iNOS and COX-2) and chief constituents (Garcinol and HCA) of Garcinia as a potent anti-inflammatory agent. The chain $\mathrm{A}$ of both iNOS and COX-2 were selected for molecular docking (Fig. 1a and b). The docking analysis indicates significant binding affinities of Garcinol and HCA with the protein targets. The present study revealed that Garcinol showed hydrogen bonding interactions with Arg199, Ile201, Leu464 and hydrophobic interactions with Met374, Tyr491, Phe369, Met355, Trp463, Val352, Tyr373, Pro350 residues of iNOS with binding energy $(\Delta G)$ of $-9.46 \mathrm{kcal} /$ mol (Fig. 9); hydrogen bonding interactions with Arg120 and hydrophobic interactions with His90, Val523, Tyr355, Arg513, Ala516, Met 522, Phe518, Leu384, Tyr385, Trp387, Phe381, Leu352, Val349, Tyr348, Leu531, Val116, Leu359 residues of COX-2 with a binding energy $(\Delta G)$ of $-4.2 \mathrm{kcal} / \mathrm{mol}$ (Fig. 10). Similarly, our study also revealed that HCA showed hydrogen bonding interactions with Thr121, Lys123, Thr126 and hydrophobic interactions with Thr109, Ile119, Pro122 residues of iNOS with binding energy $(\Delta G)$ of $-3.11 \mathrm{kcal} / \mathrm{mol}$ (Fig. 11); hydrogen bonding interaction with Lys83, Tyr115, Arg120, Glu524 

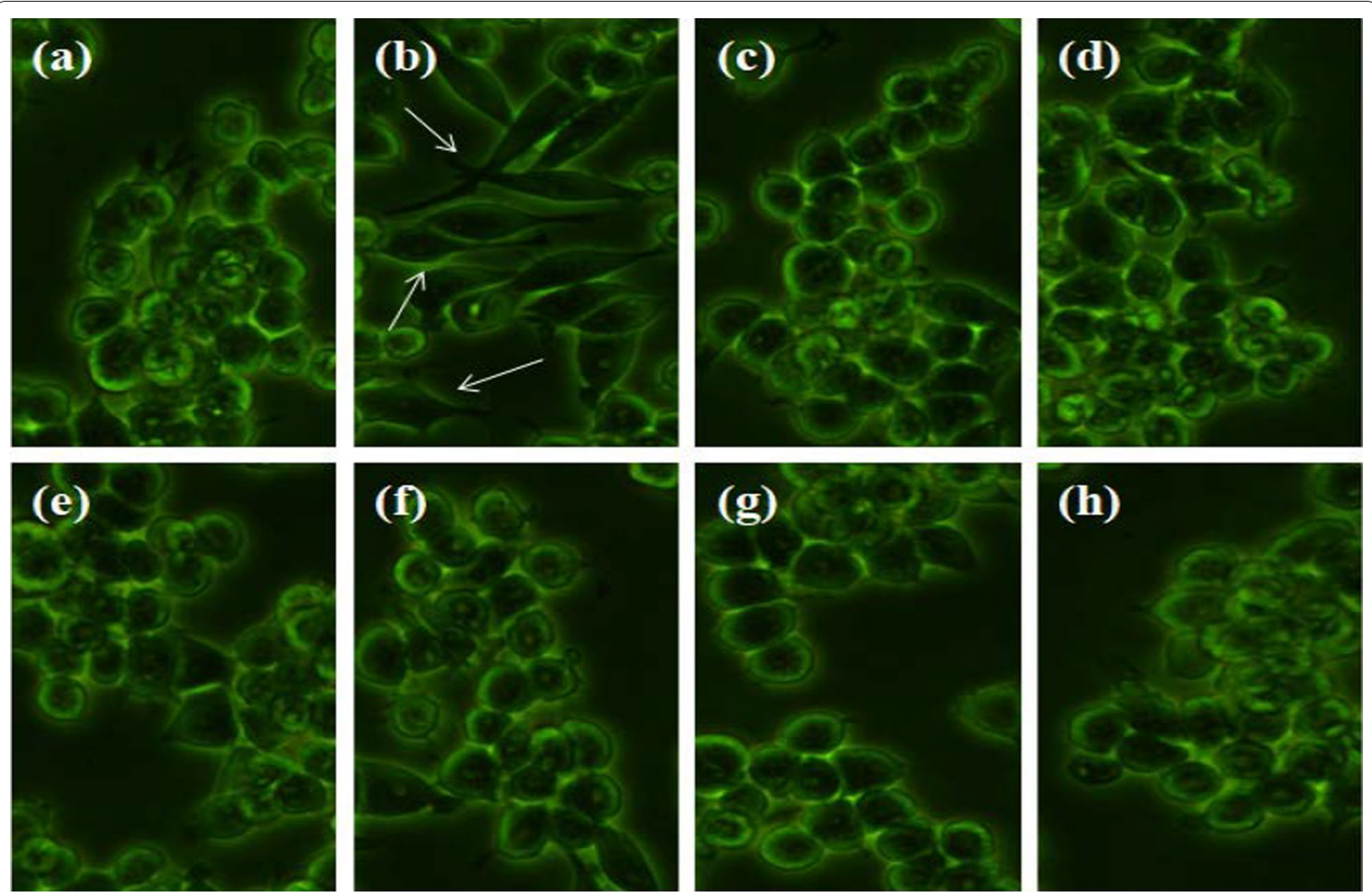

Fig. 6 Effect of different treatments on RAW264.7 murine macrophage cells. Changes of the morphology were observed under microscope and photographs were taken with Zeiss Zen blue inverted microscope. a Control, b LPS treatment, c GME $(115 \mu \mathrm{g} / \mathrm{ml})+\mathrm{LPS}$ treatment $\mathbf{d}$ GME$(230 \mu \mathrm{g} /$ $\mathrm{ml})+$ LPS treatment e Garcinol $(6 \mu \mathrm{M})+$ LPS treatment $\mathbf{f}$ Garcinol $(12 \mu \mathrm{M})+$ LPS treatment $\mathbf{g ~ H C A}(17.5 \mu \mathrm{g} / \mathrm{ml})+\mathrm{LPS}$ treatment $\mathbf{h} \mathrm{HCA}(35 \mu \mathrm{g} /$ $\mathrm{ml})+$ LPS treatment. RAW 264.7 cells were cultured in 100-mm dishes at a density of $10^{6} \mathrm{cell} / \mathrm{s} / \mathrm{cm}^{2}$ and allowed to settle for $16 \mathrm{~h}$. After $16 \mathrm{~h}$ of incubation, the medium was discarded and the cells were pre-treated as mentioned above. The cells were then stimulated with $1 \mu \mathrm{g} / \mathrm{ml} \mathrm{LPS}$ for $24 \mathrm{~h}$ except for the control group. A typical experimental result of three independent experiments is represented

and hydrophobic interactions with Pro84, Pro86, Ser 119, Tyr122 residues of COX-2 with binding energy $(\Delta G)$ of $-3.15 \mathrm{kcal} / \mathrm{mol}$ (Fig. 12).

\section{Discussion}

Garcinia is widely distributed in the tropical region and has been traditionally used in medicinal folklore with little understanding of the actual mechanism of its therapeutic action. It is one of the most important medicinal plants that have been used traditionally for its medicinal value. Earlier studies have demonstrated that Garcinia possesses anti-bacterial, anti-cancer, antioxidant activities as well as emerging anti-inflammatory potential [48-50]. The pharmacological effects of Garcinia may be primarily due to the presence of compounds such as hydroxycitric acid (HCA), Garcinol, and isogarcinol. [2224]. From our previous studies, it has been established that Garcinia herbal extract consists of several important phytoconstituents like Garcinol and HCA. In our previous studies using the LPS-challenged rat model, it was established that Garcinia herbal extract could potentially inhibit the inos and cox-2 mRNA expressions and decrease subsequent production of NO and PGE2 [33]. Therefore, this study was undertaken to establish the inhibitory action of Garcinia extract supplement and its important phytoconstituents Garcinol and HCA against iNOS and COX-2 targets in vitro. The present study investigated the inhibitory action of GME, Garcinol, and HCA against inos and cox-2 mRNA expressions. In addition, quantitative analysis was done to study the effects of GME, Garcinol, and HCA on the production of TNO and PGE2 in LPS-stimulated murine macrophage RAW264.7 cells. Also, molecular docking analysis was performed to study the interactions of Garcinol and HCA with iNOS and COX-2 proteins. In this study, the test for Mycoplasma contamination was performed before the experiments and was found to be negative. The cells on treatment with different concentrations of LPS after $24 \mathrm{~h}$ showed a significant increase in the production of total nitric oxide levels. The results of the nitric oxide assay 


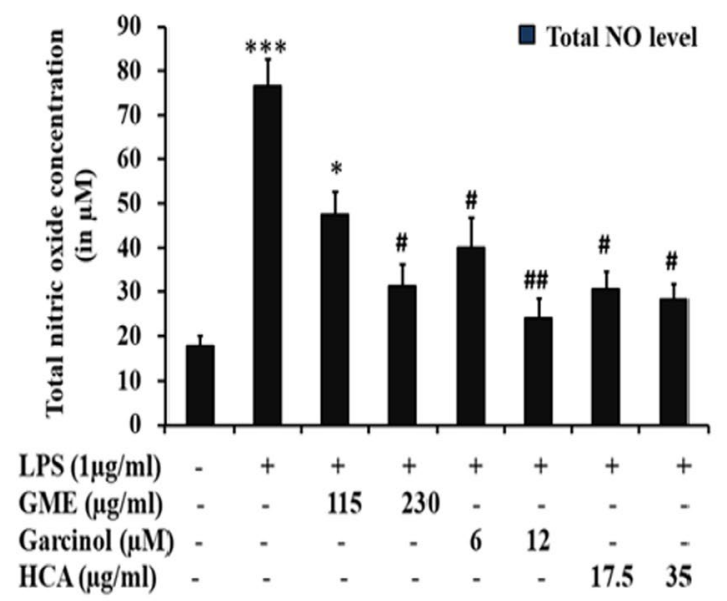

(a)

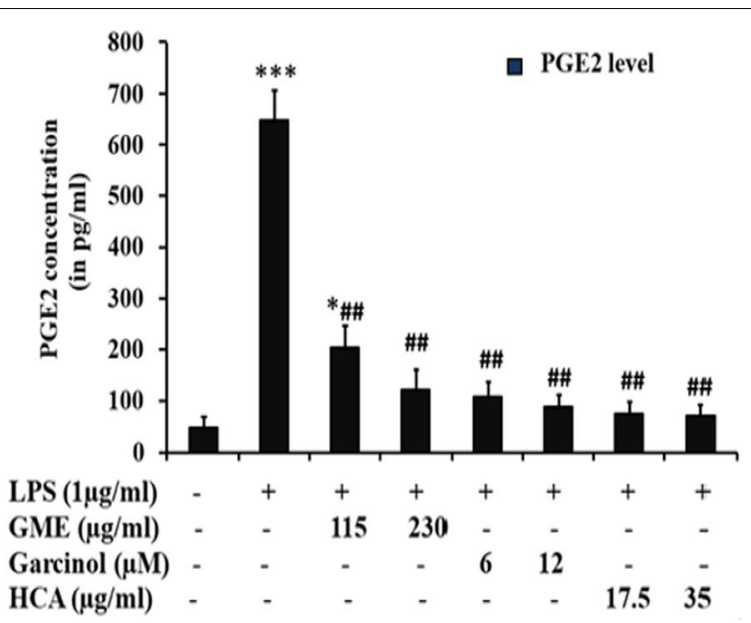

(b)

Fig. 7 Effects of GME, Garcinol and HCA on a total nitric oxide (TNO) level and b prostaglandin E2 (PGE2) level in LPS-stimulated RAW264.7 cells. Cells were treated with GME $(115 \mu \mathrm{g} / \mathrm{ml}$ and $230 \mu \mathrm{g} / \mathrm{ml}) ;$ Garcinol $(6 \mu \mathrm{M}$ and $12 \mu \mathrm{M}) ; \mathrm{HCA}(17.5 \mu \mathrm{g} / \mathrm{ml}$ and $35 \mu \mathrm{g} / \mathrm{ml})$ before LPS $(1 \mu \mathrm{g} / \mathrm{ml})$ stimulation followed by $24-\mathrm{h}$ incubation. The data represented are the mean \pm SEM. ${ }^{*} p<0.05,{ }^{* *} p<0.01,{ }^{* * *} p<0.001 \mathrm{vs}$. the control group; $\# p<0.05$, $\# \#<0.01$, \#\#\#p $<0.001$ vs. the LPS group

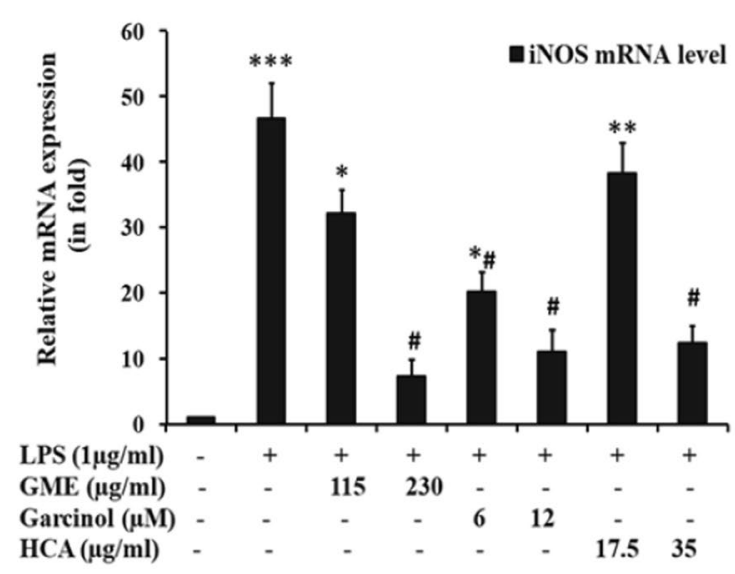

(a)

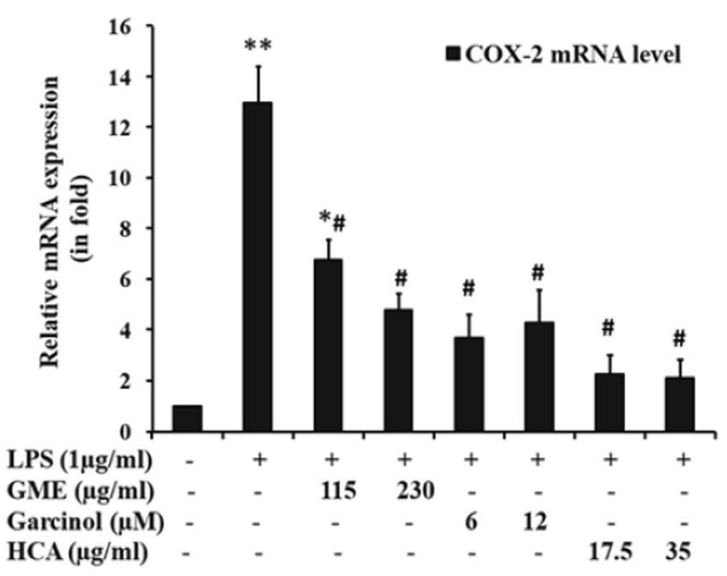

(b)

Fig. 8 Effects of GME, Garcinol and HCA on the mRNA expression levels of $\mathbf{a}$ inos and $\mathbf{b}$ cox-2 in LPS-stimulated RAW264.7 cells. Cells were pretreated with GME $(115 \mu \mathrm{g} / \mathrm{ml}$ and $230 \mu \mathrm{g} / \mathrm{ml})$; Garcinol $(6 \mu \mathrm{M}$ and $12 \mu \mathrm{M}) ; \mathrm{HCA}(17.5 \mu \mathrm{g} / \mathrm{ml}$ and $35 \mu \mathrm{g} / \mathrm{ml})$ before LPS $(1 \mu \mathrm{g} / \mathrm{ml}) \mathrm{stimulation}$ followed by $24 \mathrm{~h}$ incubation. Total RNA was extracted and analyzed by real-time qPCR. Levels of inos and cox-2 transcripts in the experimental groups are expressed as fold-changes relative to control group after being normalized against gapdh standard. The data represented are the

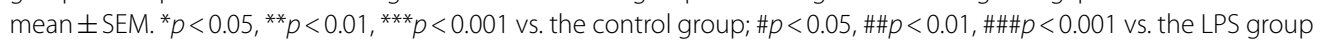

and PGE2 estimation revealed that there was a significant increase in the TNO level after $24 \mathrm{~h}$ of LPS exposure as compared to control. On the other hand, its levels were found to significantly decrease in GME, Garcinol and HCA pre-treated cells as compared to the LPS treated cells (Fig. 7a and b).

The real-time qPCR studies revealed a significant increase in the transcript levels of inos, and cox-2 after
$24 \mathrm{~h}$ of LPS treatment which was found to significantly decrease in GME, Garcinol and HCA pre-treated cells as compared to the LPS treated cells (Fig. 8a and b). It has been well-established that $\mathrm{NO}$ is a pro-inflammatory mediator [51]. The reduction in NO and PGE2 production in GME, Garcinol, and HCA-treated cells can thus be attributed to the decreased expression of inos and cox-2, respectively. iNOS is the enzyme principally 


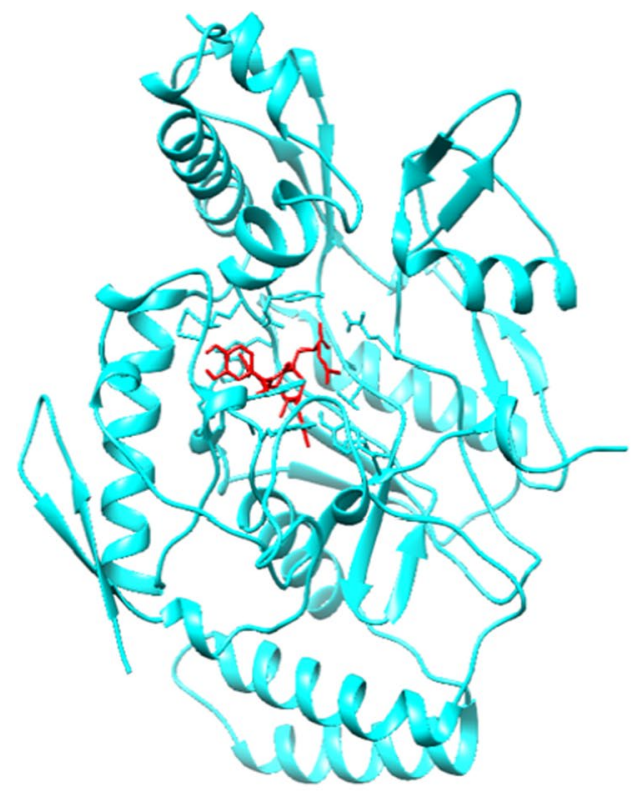

(a)

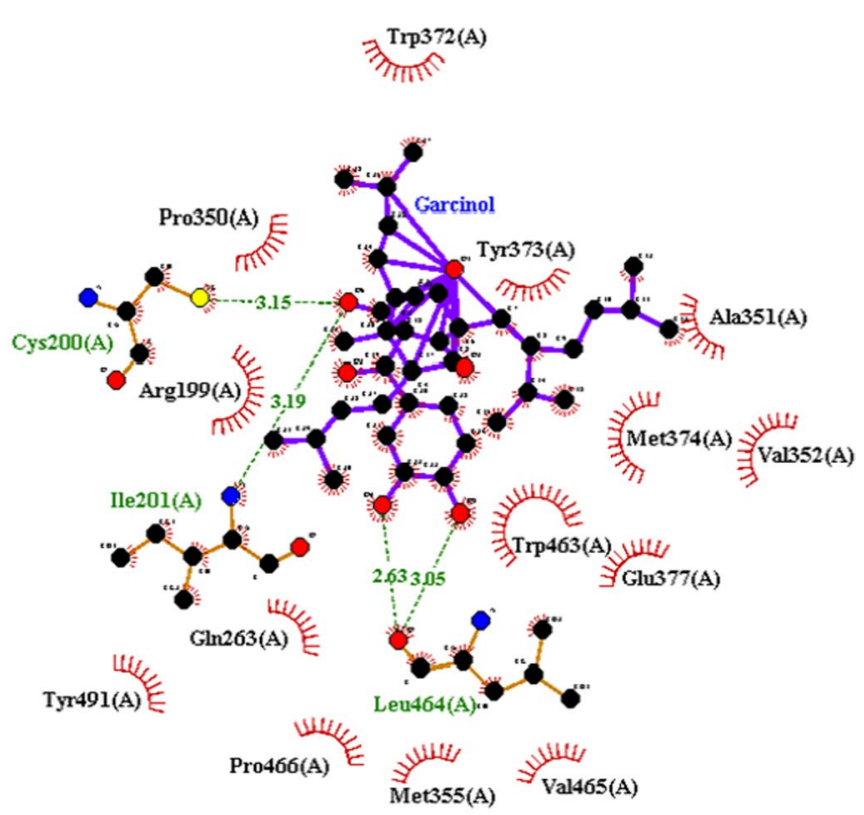

(b)

Fig. 9 Docking images of protein (iNOS) and ligand (Garcinol). a Shows the 3D interaction between garcinol (red) and iNOS (blue). b LigPlot + image showing the H-bond interactions (Cys200, lle201, Leu464) and hydrophobic interactions (Arg199, GIn263, Trp372, Pro350, Tyr373, Ala351, Met374, Val352, Trp463, Glu377, Val465, Met355, Pro466, Tyr491) between Garcinol and COX-2

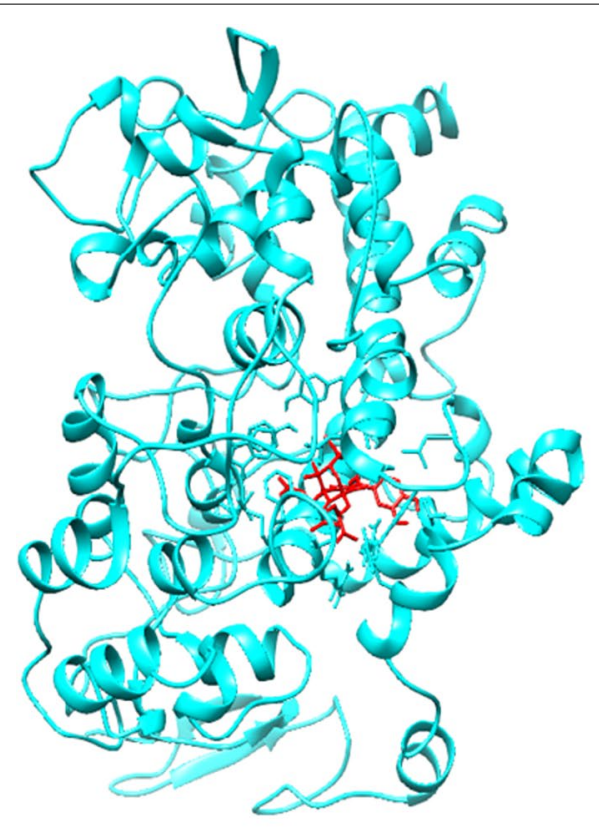

(a)

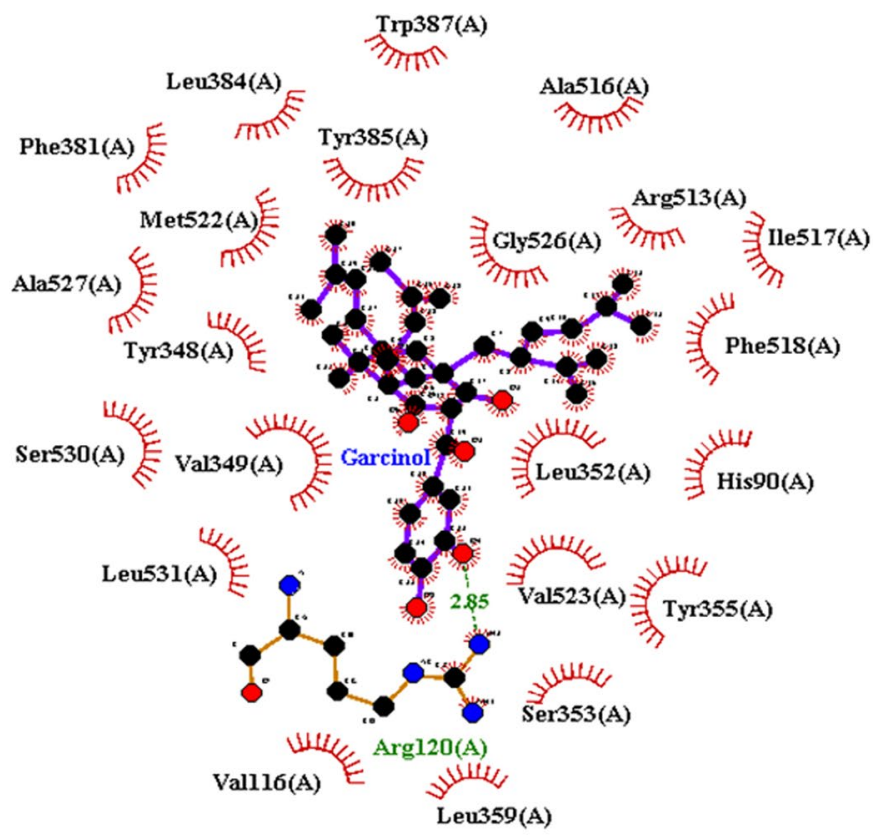

(b)

Fig. 10 Docking images of protein (COX-2) and ligand (Garcinol). a Shows the 3D interaction between garcinol (red) and COX-2(blue). b LigPlot + image showing the H-bond interactions (Arg120) and hydrophobic interactions (Trp387, Ala516, Arg513, Tyr385, Leu384, Gly526, Ile517, Phe518, His90, Leu352, Val523, Ser353, Leu359, Val116, Leu531, Ser530, Val349, Tyr348, Ala527, Met522, Phe381) between Garcinol and COX-2 


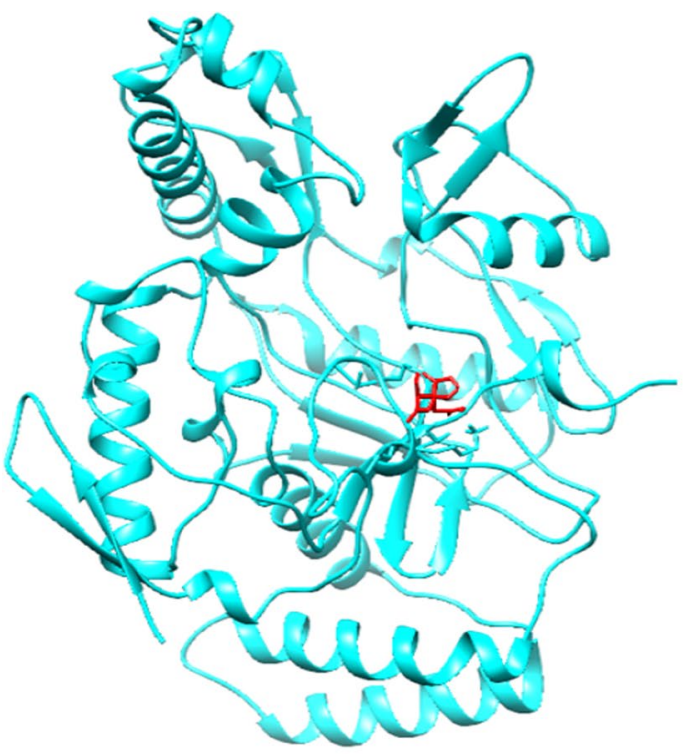

(a)

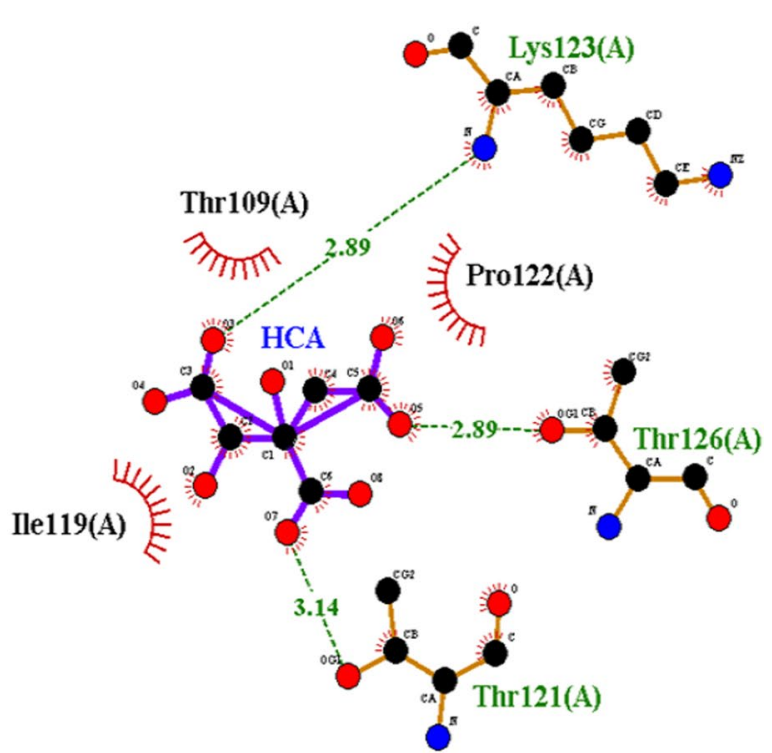

(b)

Fig. 11 Docking images of protein (iNOS) and ligand (Hydroxycitric acid). a Shows the 3D interaction between HCA (red) and iNOS (blue). b LigPlot + image showing the H-bond (Thr121, Lys123, Thr126) interactions and hydrophobic interactions (Thr109, Ile1 19, Pro122) between HCA and iNOS

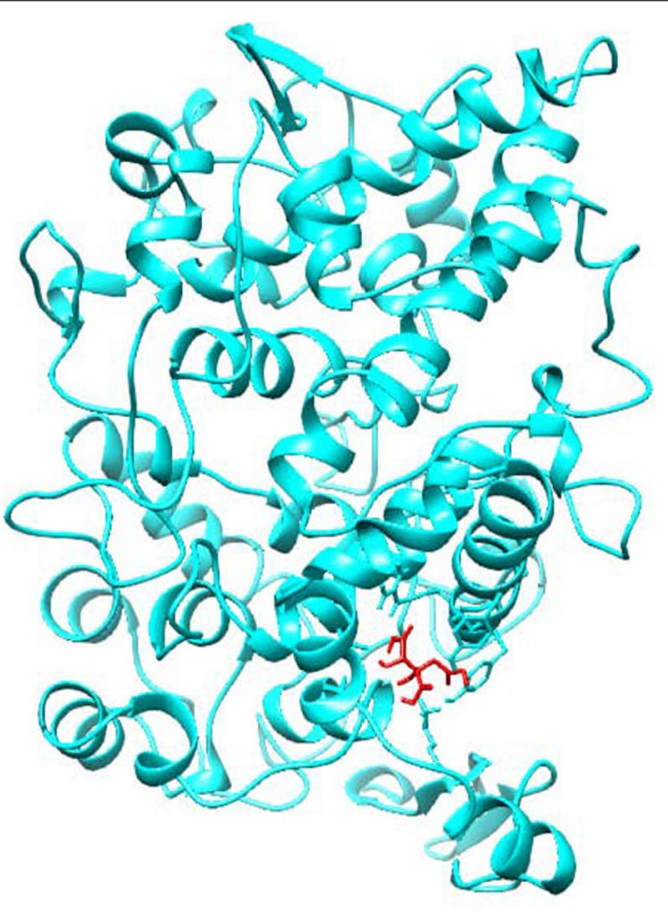

(a)

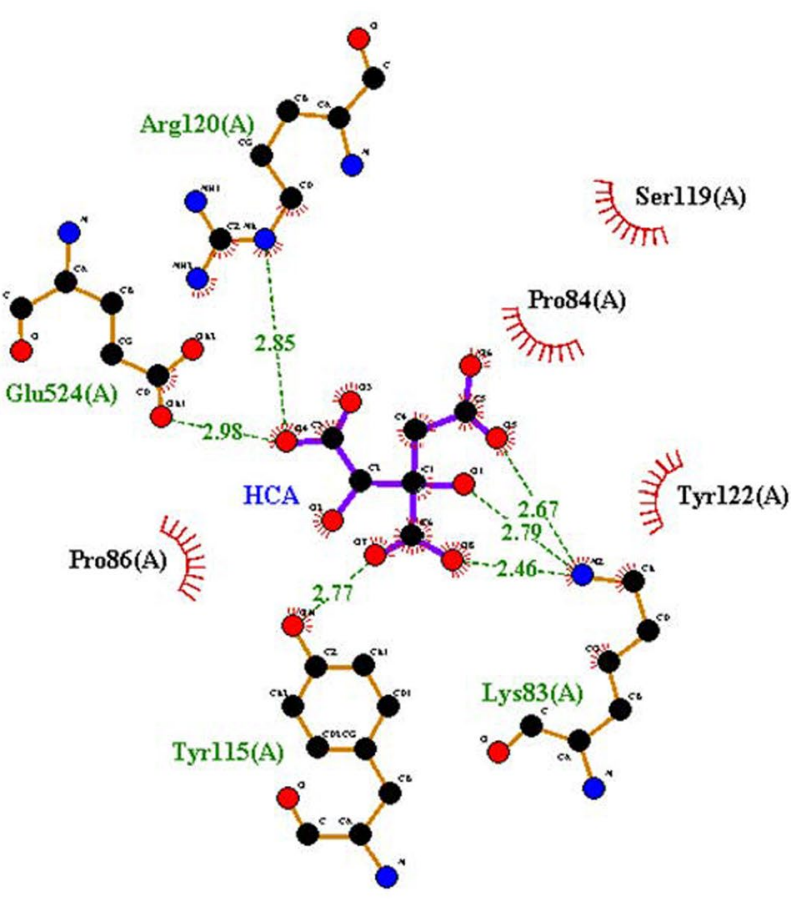

(b)

Fig. 12 Docking images of protein (COX-2) and ligand (Hydroxycitric acid). a Shows the 3D interaction between HCA (red) and COX-2 (blue). b LigPlot + image showing the H-bond interactions (Lys83, Tyr115, Arg120, Glu524) and hydrophobic interactions (Pro84, Pro86, Ser 119, Tyr122) between HCA and COX-2 
responsible for NO in inflammation. iNOS is not usually expressed in resting cells but is however induced by some cytokines as well as microbial agents $[52,53]$. Studies have reported stimuli like LPS and certain cytokines cause the expression of iNOS along with the production of pro-inflammatory mediators, such as prostaglandin and prostacyclin, through the COX pathway [54, 55]. $\mathrm{NO}$ is known to elevate the synthesis of prostaglandin by activating the constitutive and inducible cyclooxygenases in many cells $[56,57]$. Evidence suggests that in macrophages, the activity of iNOS and COX-2 induces the release of several pro-inflammatory mediators including NO and certain cytokines (Tumor necrosis factor- $\alpha$ and interleukins) $[58,59]$. Hence, the inhibition of iNOS and COX-2 is an important step toward the prevention of inflammation. Inducible nitric oxide synthase catalyzes the production of a large amount of NO during the inflammatory condition. Therefore, iNOS inhibitors are essential for healing nitric oxide-mediated inflammatory responses [60]. Moreover, herbal inhibitors such as Garcinia might play an important role as safe modulators of $\mathrm{NO}$ in the pathogenesis of inflammation. Similarly, COX-2 catalyzes the production of proinflammatory PGE2 and is known to be highly expressed during inflammation [61, 62]. From the present observations, it is found that Garcinia can act as a potential inhibitor of LPS-induced NO and PGE2 production. This inhibition might be due to the blocking of major downstream signaling involved in the production of these inflammatory mediators. However, the actual mechanism of inhibition is still unclear. It has been reported that Garcinia mangostana extracts induce anti-inflammatory action by decreasing the LPS-induced cytokine and PGE2 levels in immortalized human gingival fibroblasts cells [11]. Similarly, Cho and Cho studied the anti-inflammatory activities of ethanol extracts of Garcinia subelliptica in macrophages. They established that non-cytotoxic concentrations of the extracts could decrease the $\mathrm{NO}$ and PGE2 generation by altering the iNOS and COX-2 expression, respectively, in LPS-induced RAW 264.7 cells. This observation is in line with our study. Further, they established that the decreased secretion of inflammatory mediators by Garcinia subelliptica was associated with a decrease in the activation of c-Jun N-terminal kinase (JNK) [62]. Evidence suggests that LPS significantly induces the secretion of proinflammatory mediators in macrophages by triggering the mitogen-activated protein kinase (MAPK) signaling. Therefore, blocking the downstream signaling including suppressing of p38, ERK, and JNK phosphorylation suggests a vital target for a therapeutic approach against inflammation [63-65].

Macrophages when stimulated by bacterial endotoxin (LPS) lead to induction of inflammatory response. Such responses involve the release of several pro-inflammatory mediators like NO and PGE2 whose production is induced by the expression of iNOS and COX-2, respectively [66, 67]. Several signaling pathways such as mitogen-activated protein kinase (MAPK) have been reported to be involved in response to LPS stimulation. Reports suggest that the binding of LPS to its receptor TLR-4 in macrophages leads to the signal transduction cascades [68-70]. The receptor-ligand complex stimulates the transcription factor nuclear factor kappaB (NF$\kappa B)$ via the activation of JNK and p38 MAPK signaling. p38MAPK is the chief signaling molecule that modulates LPS-induced iNOS and COX-2 expression in macrophages $[71,72]$. Stimulation of the p38MAPK is known to carry out NF- $\mathrm{kB}$ translocation via phosphorylation of $\mathrm{IkB} \alpha$ [73]. Garcinol has been found to suppress the NF- $\mathrm{kB}$ signaling in LPS-activated macrophages. Karin et al. established that Karcinol could inhibit phosphorylation of $\mathrm{IkB} \alpha$ on serine 32 in RAW264.7 cells [74].

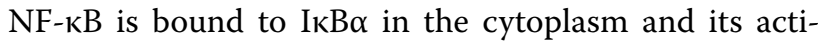
vation leads to its translocation from cytoplasm to the nucleus thus leading to the expression of inflammatory genes such as iNOS, COX2, and IL-6 [75]. Garcinol has been known to inhibit LPS-induced COX-2 expression through decreased expression of NF- $\mathrm{kB}$ and suppression of the p38 MAPK signaling pathway [50]. Earlier reports have suggested that Garcinol inhibits LPS-induced iNOS expression [49]. Therefore, based on previous reports our results indicate that Garcinol might inhibit the LPSinduced NF- $\mathrm{KB}$ translocation through suppression of $\mathrm{p} 38$ MAPK and thereby decreasing the expression of COX-2 and iNOS. Similarly, studies in animal models suggest that HCA suppresses inflammatory markers in certain tissues and serum [76]. HCA has been reported to modulate experimental autoimmune encephalomyelitis (EAE), somewhat, by inhibiting the serum NO production. HCA could decrease the serum NO levels possibly under the controlled regulation of NF- $\mathrm{kB}$ and MAPKs pathways in EAE mice [77]. Also, reports suggest that HCA could regulate the cytokine signaling in many of cell types, such as macrophages, via the inhibition of NF- $\mathrm{kB}$ and mostly by inhibiting STAT-1 nuclear transfer and DNA binding [78].

Molecular docking studies were performed to elucidate the interaction between the targets (iNOS and COX-2) and Garcinol as well as HCA as a potent inhibitor. The molecular properties of ligands (Garcinol and HCA) calculated using the Molinspiration tool showed that HCA showed zero violations against Lipinski's rule of five. However, Garcinol showed two violations against the rule of five (Table 2). Therefore, it suggests that the bioavailability of HCA is more since it follows Lipinski's rule of five, and Garcinol is therefore considered to be poorly 
absorbed. Although the 'rule-of-five' is used to detect the bioavailability of the oral drug, however, no more than $51 \%$ of all FDA-approved small-molecule drugs are both used orally and obey the thumb rule which does not even include the increasing number of biological compounds of which more than a few have achieved success [79].

Certain bioactive compounds having anti-inflammatory effects isolated from various medicinal plants have been studied through molecular docking against iNOS and COX-2 [80]. In the present study, molecular docking analysis of Garcinol and HCA against iNOS and COX-2 proteins showed good binding affinities (Figs. 9, 10, 11, 12). Molecular docking studies were performed to elucidate the interaction between the targets (iNOS and COX2) and chief constituents (Garcinol and HCA) of Garcinia as a potent anti-inflammatory agent. The docking analysis indicates significant binding affinities of Garcinol and HCA with the protein targets. The H-bond formation together with the hydrophobic interactions indicates that Garcinol, as well as HCA other than the anti-inflammatory drugs, could prove to be a potent inhibitor of iNOS and COX-2. Studies have shown that anti-inflammatory drugs (NSAIDs) such as dexamethasone and indomethacin inhibit iNOS and COX-2 [5, 81]. NSAIDs like sodium diclofenac and ibuprofen have shown interaction with iNOS with binding energy $(\Delta G)$ of about $-6.7 \mathrm{kcal} / \mathrm{mol}$ and $-7.50 \mathrm{kcal} / \mathrm{mol}$, respectively $[82,83]$. Also, it has been reported that diclofenac binds to Ser530 and Tyr 385 residues of the COX-2 active site [84]. Several studies have reported many natural inhibitory ligands for iNOS and COX-2 by molecular docking analysis [82, 84-88]. It is well-established that non-steroidal anti-inflammatory drugs (NSAIDS) operate by suppressing the release of prostaglandins by inhibiting COX-2. Synthetic drugs such as Ibuprofen and Naproxen have been reported to prevent the release of prostaglandins. Reports suggest that molecular docking of inhibitory drugs such as Ibuprofen as well as Naproxen against COX-2 showed involvement of Arg120 and Tyr355 amino acid residues [89]. Studies have also revealed Xanthone derivatives inhibit the COX enzyme that shows contact with Arg120, Ser 530, Met522, Tyr 355, Tyr385, Ser353 of the enzyme [86]. Similarly, our findings demonstrate that HCA interacts with COX-2 forming H-bonds with Arg120. Studies have reported that molecular docking of certain flavonoids including quercetin against iNOS involved the interactions with the active site residues Ile119, Thr109, Ser118, Trp461, Met480 that suggested causing inhibition of iNOS $[90,91]$. This is in agreement with the present study which showed favorable interaction of HCA with iNOS effectively involving Ile119 as well as Thr109 amino acid residues. Such potential molecular affinity of HCA provides a vast possibility for safe drug design.
Curcuminoids have been used as potential agents to block iNOS and COX-2 [82, 92]. Studies have shown that curcumin binds with iNOS with $\Delta \mathrm{G}$ of $-6.8 \mathrm{kcal} / \mathrm{mol}$ [82]. Other phytocompounds like quercetin have been found to efficiently interact with iNOS active residues compared to tetrahydrobiopterin, an iNOS inhibitor [93]. Similarly, curcumin analogues are known to interact with Ser530 residue of COX by H-bond [84]. Also, Xanthone derivatives were observed to be potent inhibitors of COX. Studies have shown the interaction of such derivatives with Arg120, Ser530, Met 522, Tyr355, Tyr 385, Ser353 residues of COX [87]. This report is in agreement with the present study. These findings showed the inhibition of the target proteins by ligand binding, which is in line with our study. The present study, therefore, provides information suggesting the possible anti-inflammatory role of Garcinia.

\section{Conclusions}

The present study demonstrated that Garcinia extract exhibited potent anti-inflammatory activity in LPSinduced RAW 264.7 cells. GME and the active phytoconstituents present, i.e., Garcinol and HCA efficiently reduced the relative mRNA expressions of inos and cox2. A significant inos and cox-2 inhibition were observed and subsequent low levels of TNO and PGE2 in the GME, Garcinol and HCA pre-incubated cells were followed by LPS incubation. Also, the molecular docking of Garcinol and HCA against iNOS and COX-2 targets revealed potent protein-ligand binding affinities. These phytoconstituents showed significant interactions with the targets with low binding energies as compared to several NSAIDs. Such binding affinities of these compounds could be linked to their inhibitory action against these targets. All these observations can be correlated to the conclusion of the anti-inflammatory effect of Garcinia. These inhibitory activities of Garcinia extract can be the basis to promote the development of anti-inflammatory drugs.

\footnotetext{
Abbreviations

GME: Garcinia methanolic extract; iNOS: Inducible nitric oxide synthase; COX-2: Cyclooxygenase-2; LPS: Lipopolysaccharide; HCA: Hydroxycitric acid; NO: Nitric oxide; PGE2: ProstaglandinE2; LC/MS: Liquid chromatography mass spectrometry; ELISA: Enzyme-linked immune sorbent assay; BLAST: Basic local alignment search tool; NCBI: National center for biotechnology information; PDB: Protein data bank; ADT: Autodock tools; CASTp: Computer atlas of surface topography of proteins; NSAIDs: Non-steroidal anti-inflammatory drugs; JNK: C-Jun N-terminal kinase; MAPK: Mitogen-activated protein kinase; ERK: Extracellular signal regulated kinase; TLR4: Toll-like receptor 4; EAE: Experimental autoimmune encephalomyelitis.
}

\section{Acknowledgements}

The authors are thankful to the Head, Department of Zoology, UGC SAP, Gauhati University, Guwahati, Assam (India), and Bioinformatics Infrastructure Facility (DBT), DST-SERB, GOI, New Delhi (India), for providing the necessary 
facilities for conducting the study. We acknowledge, HRD-DHR, ICMR New Delhi (India) for providing the financial support.

\section{Authors' contributions}

MD designed the study and critically revised the manuscript for additional valuable content. AK performed the experiments, analyzed and interpreted the data and drafted the manuscript. BD and MRB revised and designed the manuscript. All authors read and approved the final manuscript.

\section{Funding}

HRD-DHR, ICMR New Delhi (India), Grant No. R.12014/02/2019-HR.

\section{Availability of data and materials}

The data that support the findings of this study are available.

\section{Declarations}

Ethics approval and consent to participate

Not applicable.

\section{Consent for publication}

Not applicable.

\section{Competing interests}

Authors declare no conflicts of interest.

Received: 23 August 2021 Accepted: 11 February 2022

Published online: 03 March 2022

\section{References}

1. Moncada S, Higgs A (2002) The L-arginine-nitric oxide pathway. New Engl J Med 329:2012. https://doi.org/10.1056/NEJM199312303292706

2. MacMicking J, Xie QW, Nathan C (1997) Nitric oxide and macrophage function. Annu Rev Immunol 15:323-350. https://doi.org/10.1146/annur ev.immunol.15.1.323

3. Nathan C, Shiloh MU (2000) Reactive oxygen and nitrogen intermediates in the relationship between mammalian hosts and microbial pathogens. Proc Natl Acad Sci USA 97:8841-8848. https://doi.org/10.1073/pnas.97.16. 8841

4. Palsson-McDermott EM, O'Neill LAJ (2004) Signal transduction by the lipopolysaccharide receptor, Toll-like receptor-4. Immunology 113:153162. https://doi.org/10.1111/j.1365-2567.2004.01976.x

5. Kurumbail RG, Stevens AM, Gierse JK, McDonald JJ, Stegeman RA, Pak JY et al (1996) Structural basis for selective inhibition of cyclooxygenase-2 by anti-inflammatory agents. Nature 384:644-648. https://doi.org/10. 1038/384644a0

6. Ricciotti E, FitzGerald GA (2011) Prostaglandins and inflammation. Arterioscler Thromb Vasc Biol. 31:986-1000. https://doi.org/10.1161/ATVBAHA. 110.207449

7. Espirito Santo BLSd, Santana LF, Kato Junior WH, de Araújo FdO, Bogo D, Freitas KdC et al (2020) Medicinal potential of Garcinia species and their compounds. Molecules 25(19):4513. https://doi.org/10.3390/molecules2 5194513

8. Parthasarathy U, Babu KN, Kumar RS, Ashis GR, Mohan S, Parthasarathy VA (2013) Diversity of Indian Garcinia: a medicinally important spice crop in India. Acta Hort 979(979):467-476

9. Parthasarathy U, Nandakishore OP (2014) Morphological characterisation of some important Indian Garcinia species. Dataset Pap Sci. https://doi. org/10.1155/2014/823705

10. Hay AEA, Mallet MC, Dumontet $S$, Litaudon V, Rondeau M, Richomme D (2004) Antioxidant xanthones from Garcinia vieillardii. J Nat Prod 67(4):707-709. https://doi.org/10.1021/np0304971

11. Lim YK, Yoo SY, Jang YY, Lee BC, Lee DS, Kook JK (2019) Anti-inflammatory and in vitro bone formation effects of Garcinia mangostana L. and propolis extracts. Food Sci Biotechnol. 29(4):539-548. https://doi.org/10.1007/ s10068-019-00697-3
12. Diaz-Carballo D, Seeber S, Strumberg D, Hilger RA (2003) Novel antitumoral compound isolated from Clusiarosea. Int J Clin Pharm 41(12):622623. https://doi.org/10.5414/CPP41622

13. Merza J, Aumond MC, Rondeau D, Dumontet V, Le Ray AM, Seraphin D et al (2004) Prenylated xanthones and tocotrienols from Garcinia virgata. Phytochemistry 65(21):2915-2920. https://doi.org/10.1016/j.phytochem. 2004.06.037

14. Mundugaru R, Narayana SKK, Ballal SR, Thomas J, Rajakrishnan R (2016) Neuroprotective activity of Garcinia pedunculata roxb ex buch ham fruit extract against aluminium chloride induced neurotoxicity in mice. Indian J Pharm Educ Res. 50(3):435-441. https://doi.org/10.5530/ijper.50.3.17

15. Chen TH, Fu YS, Chen SP, Fuh YM, Chang C, Weng CF (2021) Garcinia linii extracts exert the mediation of anti-diabetic molecular targets on antihyperglycemia. Biomed Pharmacother 134:111151. https://doi.org/10. 1016/j.biopha.2020.111151

16. Abood WN, Bradosty SW, Shaikh FK, Salehene NA, Farghadani R, Aghag NFS et al (2020) Garcinia mangostana peel extracts exhibit hepatoprotective activity against thioacetamide-induced liver cirrhosis in rats. J Funct Foods 74:104200. https://doi.org/10.1016/j.jff.2020.104200

17. Demenciano SC, Silva MCBL, Alexandrino CAF, Junior WHK, Figueiredo PO, Garcez WS et al (2020) Antiproliferative activity and antioxidant potential of extracts of Garcinia gardneriana. Molecules 25(14):3201. https://doi.org/10.3390/molecules25143201

18. Badmus JA, Adedosu OT, Adeleke EG, Akinboro KH, Odeyemi BI, Ayoola BI et al (2014) In vitro and in vivo biochemical evaluations of the methanolic leaf extract of Garcinia kola. Int Sch Res Notices 2014:391692. https://doi. org/10.1155/2014/391692

19. Khanum SA, Shashikanth S, Deepak AV (2004) Synthesis and anti-inflammatory activity of benzophenone analogues. Bioorg Chem 32(4):211222. https://doi.org/10.1016/j.bioorg.2004.04.003

20. Padhye S, Ahmad A, Oswal N, Sarkar FH (2009) Emerging role of Garcinol, the antioxidant chalcone from Garcinia indica Choisy and its synthetic analogs. J Hematol Oncol 2:38. https://doi.org/10.1186/1756-8722-2-38

21. Baliga MS, Bhat HP, Pai RJ, Boloor R, Princy LP (2011) The chemistry and medicinal uses of the underutilized Indian fruit tree Garcinia indica Choisy (kokum): a review. Food Res Int 44(7):1790-1799

22. Heymsfield SB, Allison DB, Vasselli JR, Pietrobelli A, Greenfield D, Nunez C (1998) Garcinia cambogia (hydroxycitric acid) as a potential antiobesity agent: a randomized controlled trial. JAMA 280(18):1596-1600. https:// doi.org/10.1001/jama.280.18.1596

23. Hemshekhar M, Sunitha K, Sebastian Santhosh M, Devaraja S, Kemparaju K, Vishwanath BS et al (2011) An overview on genus Garcinia: phytochemical and therapeutical aspects. Phytochem Rev. 10:325-51. https:// doi.org/10.1007/s11101-011-9207-3

24. Jayaprakash GK, Sakariah KK (2000) Determination of (-)-hydroxycitric acid in commercial samples of Garcinia cambogia extracts by liquid chromatography using ultraviolet detection. J Liq Chromatogr Relat Technol 23:915-923. https://doi.org/10.1081/JLC-100101498

25. Liu C, Ho PC, Wong FC, Sethi G, Wang LZ, Goh BC (2015) Garcinol: current status of its anti-oxidative, anti-inflammatory and anti-cancer effects. Cancer Lett. 362:8-14. https://doi.org/10.1016/j.canlet.2015.03.019

26. Huang MT, Liu Y, Badmaev V, Ho CT (2008) Antiinflammatory and anticancer activities of Garcinol. Dietary Suppl 20:293-303. https://doi.org/10. 1021/bk-2008-0987.ch020

27. Jia Y, Pang C, Zhao K, Jiang J, Zhang T, Peng J et al (2019) Garcinol suppresses IL-1 $\beta$-induced chondrocyte inflammation and osteoarthritis via inhibition of the NF-kB signaling pathway. Inflammation 42:1754-1766. https://doi.org/10.1007/s10753-019-01037-7

28. Jena BS, Jayaprakash GK, Sakariah KK (2000) Organic acids from leaves, fruits, and rinds of Garcinia cowa. J Agric Food Chem 50:3431-3434. https://doi.org/10.1021/jf011627j

29. Kim JE, Jeon SM, Park KH, Lee WS, Jeong TS, McGregor RA et al (2011) Does Glycine max leaves or Garcinia cambogia promote weight-loss or lower plasma cholesterol in overweight individuals: a randomized control trial. Nutr J. 10:94. https://doi.org/10.1186/1475-2891-10-94

30. Haller CA (2004). Weight reduction therapies: anorectants, thermogenics, and lipolytics. In: Principles of gender-specific medicine. 874-881

31. Amin KA, Kamel HH, Abd Eltawab MA (2011) Protective effect of Garcinia against renal oxidative stress and biomarkers induced by high fat and sucrose diet. Lipids Health Dis. 10:6. https://doi.org/10.1186/ $1476-511 X-10-6$ 
32. dos Reis SB, de Oliveira CC, Acedo SC, Miranda DD, Ribeiro ML, Pedrazzoli J et al (2009) Attenuation of colitis injury in rats using Garcinia cambogia extract. Phytother Res 23(3):324-329. https://doi.org/10.1002/ptr.2626

33. Kalita A, Das M, Baro MR, Das B (2021) Exploring the role of Aquaporins (AQPs) in LPS induced systemic inflammation and the ameliorative effect of Garcinia in male Wistar rat. Inflammopharmacology. https://doi.org/10. 1007/s10787-021-00832-9

34. Young L, Sung J, Stacey G, Masters JR (2010) Detection of Mycoplasma in cell cultures. Nat Protoc. 5(5):924-934. https://doi.org/10.1038/nprot. 2010.43

35. Uphoff CC, Drexler HG (2013) Detection of mycoplasma contaminations. Methods Mol Biol 946:1-13

36. Parasramk MA, Gupta SV (2012) Synergistic effect of garcinol and curcumin on antiproliferative and apoptotic activity in pancreatic cancer cells. J Oncol 2012:709739. https://doi.org/10.1155/2012/709739

37. Kibbe WA (2007) OligoCalc: an online oligonucleotide properties calculator. Nucleic Acids Res. 35:43-46. https://doi.org/10.1093/nar/gkm234

38. Livak KJ, Schmittgen TD (2001) Analysis of relative gene expression data using real-time quantitative PCR and the $2-\triangle \triangle C T$ method. Methods 25(4):402-408. https://doi.org/10.1006/meth.2001.1262

39. Kubista M, Andrade J, Bengtsson M, Forootan A, Jonák J, Lind K, et al (2006). The real-time polymerase chain reaction. Mol Aspects Med. 2006; 27(2-3): 95-125

40. Molinspiration cheminformatics, Nova ulica, SK-900 26 Slovensky Grob, Slovak Republic, 2013, http://www.molinspiration.com

41. Lipinski CA, Lombardo F, Dominy BW, Feeney PJ (2001) Experimental and computational approaches to estimate solubility and permeability in drug discovery and development settings. Adv Drug Deliv Rev 46(1-3):3-26. https://doi.org/10.1016/s0169-409x(00)00129-0

42. CHEMSPIDER, http://www.chemspider.com/.

43. Morris GM, Huey R, Lindstrom W, Sanner MF, Belew RK, Goodsell DS et al (2009) AutoDock4and AutoDock Tools4: automated docking with selective receptor flexibility. J Comput Chem 30(16):2785-2791. https://doi. org $/ 10.1002 / j c c .21256$

44. Kim S, Thiessen PA, Bolton EE, Chen J, Fu G, Gindulyte A et al (2015) PubChem substance and compound databases. Nucleic Acids Res. 44(D1):D1202-D1213. https://doi.org/10.1093/nar/gkv951

45. O'Boyle NM, Banck M, James CA, Morley C, Vandermeersch T, Hutchison GR (2011) Open Babel: an open chemical toolbox. J Chemoinform 3:33. https://doi.org/10.1186/1758-2946-3-33

46. Tian W, Chen C, Lei X, Zhao J, Liang J. CASTp 30: Computed atlas of surface topography of proteins. Nucleic Acids Res. 46(1): 363-367

47. Wallace AC, Laskowski RA, Thornton JM (1995) LIGPLOT: A program to generate schematic diagrams of protein-ligand interactions. Prot Eng 8(2):127-134. https://doi.org/10.1093/protein/8.2.127

48. Tanaka T, Kohno H, Shimada R, Kagami S, Yamaguchi F, Kataoka S et al (2000) Prevention of colonic aberrant crypt foci by dietary feeding of garcinol in male F344 rats. Carcinogenesis 21:1183-1189

49. Tsai ML, Chiou YS, Chiou LY, Ho CT, Pan MH (2014) Garcinol suppresses inflammation-associated colon carcinogenesis in mice. Mol Nutr Food Res. 58:1820-29

50. Liao CH, Sang S, Liang YC, Ho CT, Lin JK (2004) Suppression of inducible nitric oxide synthase and cyclooxygenase- 2 in downregulating nuclear factor-kappa B pathway by Garcinol. Mol Carcinog 41:140-149. https:// doi.org/10.1002/mc.20050

51. Bosca'L, Zeinia M, Traves' PG, Hortelanoa S, (2005) Nitric oxide and cell viability in inflammatory cells: a role for $\mathrm{NO}$ in macrophage function and fate. Toxicology 208:249-258. https://doi.org/10.1016/j.tox.2004.11.035

52. Geller DA, Billiar TR (1998) Molecular biology of nitric oxide synthases. Cancer Metastasis Rev 17:7-23. https://doi.org/10.1023/a:1005940202801

53. Stuehr DJ (1999) Mammalian nitric oxide synthases. Biochim Biophys Acta 1411:217-230. https://doi.org/10.1016/s0005-2728(99)00016-x

54. Nathan CF (1987) Secretory products of macrophages. J Clin Invest 79:319-326. https://doi.org/10.1172/JCl112815

55. Salvemini D, Misko TP, Masferrer UL, Seibert K, Currie MG, Needleman P (1993) Nitric oxide activates cyclooxygenase enzymes. Proc Natl Acad Sci USA 90:7240-7244. https://doi.org/10.1073/pnas.90.15.7240

56. Swierkosz TA, Mitchell JA, Warner TD, Botting RM, Vane JR (1995) Coinduction of nitric oxide synthase and cyclo-oxygenase: interactions between nitric oxide and prostanoids. Br J Pharmacol 114:1335-1342. https://doi.org/10.1111/j.1476-5381.1995.tb13353.x
57. Chang YC, Yang SF, Huang FM, Liu CM, Tai KW, Hsieh YS (2003) Proinflammatory cytokines induce cyclooxygenase-2 mRNA and protein expression in human pulp cell cultures. J Endod 29:201-204. https://doi.org/10. 1097/00004770-200303000-00009

58. Hesse AK, Dörger M, Kupatt C, Krombach F (2014) Proinflammatory role of inducible nitric oxide synthase in acute hyperoxic lung injury. Respir Res 5:11. https://doi.org/10.1186/1465-9921-5-11

59. Knowles RG, Moncada S (1994) Nitric oxide synthases in mammals. Biochem J. 298(2):249-58. https://doi.org/10.1042/bj2980249

60. Nørregaard R, Kwon TH, Frøkiær J (2015) Physiology and pathophysiology of cyclooxygenase-2 and prostaglandin E2 in the kidney. Kidney Res Clin Pract. 34(4):194-200. https://doi.org/10.1016/j.krcp.2015.10.004

61. Tang T, Scambler TE, Smallie T, Cunliffe HE, Ross EA, Rosner DR et al (2017) Macrophage responses to lipopolysaccharide are modulated by a feedback loop involving prostaglandinE2, dual specificity phosphatase 1 and tristetraprolin. Sci Rep. 7(1):4350. https://doi.org/10.1038/ s41598-017-04100-1

62. Cho YC, Cho S (2016) C-Jun N-terminal kinase-mediated anti-inflammatory effects of Garcinia subelliptica in macrophages. Mol Med Rep. 13(3):2293-2300. https://doi.org/10.3892/mmr.2016.4791

63. Fujihara M, Muroi M, Tanamoto K, Suzuki T, Azuma H, Ikeda H (2003) Molecular mechanisms of macrophage activation and deactivation by lipopolysaccharide: Roles of the receptor complex. Pharmacol Ther. 100(2):171-194. https://doi.org/10.1016/j.pharmthera.2003.08.003

64. Schroder K, Sweet MJ, Hume DA (2006) Signal integration between IFNgamma and TLR signalling pathways in macrophages. Immunobiology. 211(6-8):511-524. https://doi.org/10.1016/j.imbio.2006.05.007

65. Cario E, Rosenberg IM, Brandwein SL, Beck PL, Reinecker HC, Podolsky DK (2000) Lipopolysaccharide activates distinct signaling pathways in intestinal epithelial cell lines expressing toll-like receptors. J Immunol. 164(2):966-972. https://doi.org/10.4049/jimmunol.164.2.966

66. Shi Q, Cao J, Fang L, Zhao H, Liu Z, Ran J et al (2014) Geniposide suppresses LPS-induced nitric oxide, $\mathrm{PGE}_{2}$ and inflammatory cytokine by downregulating NF-KB, MAPK and AP-1 signaling pathways in macrophages. Int Immunopharmacol. 20(2):298-306. https://doi.org/10 1016/j.intimp.2014.04.004

67. Jang HL, El-Gamal Ml, Choi HE, Choi HY, Lee KT, Oh CH (2014) Synthesis of tricyclic fused coumarin sulfonates and their inhibitory effects on LPSinduced nitric oxide and PGE2 productions in RAW 264.7 macrophages. Bioorg Med Chem Lett. 24(2):571-575. https://doi.org/10.1016/j.bmcl. 2013.12.018

68. Bowie A, O'Neill LAJ (2000) Nuclear factor-kB activation and innate immune response in microbial pathogen infection. Biochem Pharmacol 60:1109-1114. https://doi.org/10.1016/s0006-2952(00)00390-7

69. Herrera-Velit P, Knutson KL, Reiner NE (1997) Phosphatidylinositol 3-kinase-dependent activation of protein kinase C-zeta in bacterial lipopolysaccharide-treated human monocytes. J Biol Chem 272:1644516452. https://doi.org/10.1074/jbc.272.26.16445

70. Lien E, Chowi JC, Hawkinsi LD et al (2001) A novel synthetic acyclic lipid A-like agonist activates cells via the lipopolysaccharide/toll-like receptor 4 signaling pathway. J Biol Chem 276:1873-1880. https://doi.org/10. 1074/jbc.M009040200

71. Nick JA, Young SK, Brown KK et al (2000) Role of p38 mitogen activated protein kinase in a murine model of pulmonary inflammation. J Immunol 164:2151-2159. https://doi.org/10.4049/jimmunol.164.4.2151

72. Chen BC, Chen YH, Lin WW (1999) Involvement of p38 mitogenactivated protein kinase in lipopolysaccharide-induced iNOS and COX-2 expression in J774 macrophages. Immuno 97:124-129. https://doi.org/10.1046/j. 1365-2567.1999.00747.x

73. Carter AB, Knudtson KL, Monick MM, Hunninghake GW (1999). The p38 mitogen-activated protein kinase is required for NFkappaB-dependent gene expression The role of TATAbinding protein (TBP). J Biol Chem 274:30858-30863.https://doi.org/10.1074/jbc.274.43.30858.

74. Karin M, Delhase M (2000) The I kappa B kinase (IKK) and NF-kappaB: Key elements of proinflammatory signalling. Semin Immunol. 12:85-98. https://doi.org/10.1006/smim.2000.0210

75. Roman-Blas JA, Jimenez SA (2006) NF-KB as a potential therapeutic target in osteoarthritis and rheumatoid arthritis. Osteoarth Cartilage 14:839848. https://doi.org/10.1016/j.joca.2006.04.008 
76. Clouatre DL, Preuss HG (2013) Hydroxycitric acid does not promote inflammation or liver toxicity. World J Gastroenterol 19:8160-8162. https://doi.org/10.3748/wjg.v19.i44.8160

77. Goudarzvand M, Afraei S, Yaslianifard S et al (2016) Hydroxycitric acid ameliorates inflammation and oxidative stress in mouse models of multiple sclerosis. Neural Regen Res 11:1610-1616. https://doi.org/10.4103/ 1673-5374.193240

78. Masullo M, Menegazzi M, Di Micco S, Beffy P, Bifulco G, Dal Bosco M et al (2014) Direct interaction of garcinol and related polyisoprenylated benzophenones of Garcinia cambogia fruits with the transcription factor STAT-1 as a likely mechanism of their inhibitory effect on cytokine signaling pathways. J Nat Prod. 77:543-549. https://doi.org/10.1021/np400804y

79. Zhang MQ, Wilkinson B (2007) Drug discovery beyond the "rule-of-five." Curr Opin Biotechnol 18(6):478-488. https://doi.org/10.1016/j.copbio. 2007.10.005

80. Thamaraiselvi L, Selvankumar T, Wesely EG, Nathan VK (2021) In-silico molecular docking analysis of some plant derived molecules for antiinflammatory inhibitory activity. Curr Bot 12:22-27

81. Moreira DR, Uberti ACMG, Gomes ARQ, Ferreira MES, Santos RS, Green MD et al (2018) Inhibition of nitric oxide synthesis by dexamethasone2 increases survival rate in Plasmodium berghei-infected mice. In Press. https://doi.org/10.1101/497966

82. Herawati H, Oktanella Y, Anisa AK (2021) Molecular docking analysis of curcuminoids from Curcuma longa extract on iNOS as an immunomodulator candidate in broilers. Adv Anim Vet Sci. 9:519-524

83. Wijaya YT, Yulandi A, Gunawan AW (2020) In silico study of anthocyanin and ternatin flavonoids for the treatment of inflammation-related diseases using molecular docking analysis. Food Res. 4:780-785

84. Rowlinson SW, Kiefer JR, Prusakiewicz J, Pawlitz JL, Kozak KR, Kalgutkar AS et al (2003) A novel mechanism of cyclooxygenase-2 inhibition involving interactions with Ser-530 and Tyr385. J Biol Chem 278:45763-45769. https://doi.org/10.1074/jbc.M305481200

85. Cario E, Rosenberg IM, Brandwein SL, Beck PL, Reinecker HC, Podolsky DK (2000) Lipopolysaccharide activates distinct signaling pathways in intestinal epithelial cell lines expressing toll-like receptors. J Immunol. 164:966-972. https://doi.org/10.4049/jimmunol.164.2.966

86. Lin JK, Lin-Shiau SY (2001) Mechanism of cancer chemoprevention by Curcumin. Proc Natl Sci Counc Repub ChinaB 25:59-66

87. Miladiyah I, Jumina J, Haryana SM, Mustofa M (2017) In silico molecular docking of xanthone derivative as cyclooxygenase-2 inhibitor agents. Int J Pharm Pharm Sci. 9:98-104

88. Gunalan G, Vijayalalakshmi K, Saraswathy A, Hopper W, Thangaraju T (2014) Anti-inflammatory activities of phytochemicals from Bauhinia variegata linn. Leaf: An in silico approach. JOCPR 6:334-348

89. Piccagli L, Fabbri E, Borgatti M, Bezzerri V, Mancini I, Nicolis E et al (2008) Docking of molecules identified in bioactive medicinal plants extracts into the p50 NF-KB transcription factor: correlation with inhibition of NF-KB/DNA interactions and inhibitory effects on IL-8 gene expression. BMC Struct Biol 8:38. https://doi.org/10.1186/1472-6807-8-38

90. Llorens O, Perez JJ, Palomer A, Mauleon D (2002) Differential binding mode of diverse cyclooxygenase inhibitors. J Mol Graph Model 20(5):359-371. https://doi.org/10.1016/s1093-3263(01)00135-8

91. Baul HS, Rajiniraja M (2018) Molecular docking studies of selected flavonoids on inducible nitric oxide synthase (iNOS) in Parkinson's disease. Res J Pharm Technol 11(8):3685-3688

92. Boroumand N, Samarghandian S, Hashemy SI (2018) Immunomodulatory, anti-inflammatory, and antioxidant effects of Curcumin. J Herbmed Pharmacol. 27: 211-219. https://doi.org/10.15171/jhp.2018.33.

93. Kim DC (2018) Identification of quercetin as a potential anti neuroinflammatory agent using BV2 microglia cell system and in silico molecular docking technology. IJERT 11:1-10

\section{Publisher's Note}

Springer Nature remains neutral with regard to jurisdictional claims in published maps and institutional affiliations.

\section{Submit your manuscript to a SpringerOpen ${ }^{\circ}$ journal and benefit from:}

- Convenient online submission

- Rigorous peer review

- Open access: articles freely available online

- High visibility within the field

- Retaining the copyright to your article

Submit your next manuscript at $\boldsymbol{\nabla}$ springeropen.com 